\title{
Stratospheric ozone depletion from future nitrous oxide increases
}

\author{
W. Wang ${ }^{1, *}$, W. Tian ${ }^{1}$, S. Dhomse ${ }^{2}$, F. Xie ${ }^{3}$, J. Shu ${ }^{4}$, and J. Austin ${ }^{5}$ \\ ${ }^{1}$ College of Atmospheric Sciences, Lanzhou University, Lanzhou, China \\ ${ }^{2}$ Institute for Climate and Atmospheric Science, School of Earth and Environment, \\ University of Leeds, Leeds, UK \\ ${ }^{3}$ College of Global Change and Earth System Science, Beijing Normal University, Beijing, China \\ ${ }^{4}$ Institute of Plateau Meteorology, China Meteorological Administration, Chengdu, China \\ ${ }^{5}$ Enigma Scientific Publications, Winnersh, Berkshire, UK \\ *now at: Freie Universität Berlin, Institut für Meteorologie, Berlin, Germany
}

Correspondence to: W. Tian (wstian@lzu.edu.cn)

Received: 8 August 2013 - Published in Atmos. Chem. Phys. Discuss.: 12 November 2013

Revised: 21 August 2014 - Accepted: 22 October 2014 - Published: 8 December 2014

\begin{abstract}
We have investigated the impact of the assumed nitrous oxide $\left(\mathrm{N}_{2} \mathrm{O}\right)$ increases on stratospheric chemistry and dynamics using a series of idealized simulations with a coupled chemistry-climate model (CCM). In a future cooler stratosphere the net yield of $\mathrm{NO}_{\mathrm{y}}$ from $\mathrm{N}_{2} \mathrm{O}$ is shown to decrease in a reference run following the IPCC A1B scenario, but $\mathrm{NO}_{\mathrm{y}}$ can still be significantly increased by extra increases of $\mathrm{N}_{2} \mathrm{O}$ over 2001-2050. Over the last decade of simulations, $50 \%$ increases in $\mathrm{N}_{2} \mathrm{O}$ result in a maximal $6 \%$ reduction in ozone mixing ratios in the middle stratosphere at around $10 \mathrm{hPa}$ and an average $2 \%$ decrease in the total ozone column (TCO) compared with the control run. This enhanced destruction could cause an ozone decline in the first half of this century in the middle stratosphere around $10 \mathrm{hPa}$, while global TCO still shows an increase at the same time. The results from a multiple linear regression analysis and sensitivity simulations with different forcings show that the chemical effect of $\mathrm{N}_{2} \mathrm{O}$ increases dominates the $\mathrm{N}_{2} \mathrm{O}$-induced ozone depletion in the stratosphere, while the dynamical and radiative effects of $\mathrm{N}_{2} \mathrm{O}$ increases are overall insignificant. The analysis of the results reveals that the ozone depleting potential of $\mathrm{N}_{2} \mathrm{O}$ varies with the time period and is influenced by the environmental conditions. For example, carbon dioxide $\left(\mathrm{CO}_{2}\right)$ increases can strongly offset the ozone depletion effect of $\mathrm{N}_{2} \mathrm{O}$.
\end{abstract}

\section{Introduction}

Stratospheric ozone destruction involves complex chemical reactions and a range of chemical species. The catalytic destruction by reactive chlorine and bromine has accounted for a large part of the ozone loss in the stratosphere over the past few decades (WMO, 2007). However, stratospheric chlorine $(\mathrm{Cl})$ and bromine $(\mathrm{Br})$ loading is now decreasing due to the reduction of emissions of anthropogenic chlorofluorocarbons (CFCs) and other halogen-containing chemicals mandated by the Montreal Protocol. Therefore, the effects of other ozone-depleting substances (ODSs) have become a subject of renewed concern in recent years (Wuebbles and Hayhoe, 2002; Chipperfield, 2003; Dentener et al., 2005; Stenke and Grewe, 2005; Ravishankara et al., 2009; Tian et al., 2009). Among other chemical species, nitrous oxide $\left(\mathrm{N}_{2} \mathrm{O}\right)$ has been recognized as an important substance affecting stratospheric ozone, and the effect of $\mathrm{N}_{2} \mathrm{O}$ on ozone depletion has been discussed in a number of studies (e.g. Crutzen, 1976; Crutzen and Ehhalt, 1977; Kinnison et al., 1988; Randeniya et al., 2002; Chipperfield, 2003). Crutzen and Ehhalt (1977) first pointed out that the increasing use of fixed nitrogen as fertilizer might result in a reduction of the Earth's ozone layer of a few percent at the beginning of the 21 st century. Portmann and Solomon (2007) found that increasing $\mathrm{N}_{2} \mathrm{O}$ could lead to a $2-4 \%$ decline of the total ozone column (TCO) by the end of this century under the IPCC A2 scenario. Ravishankara et al. (2009) re-opened the debate on the importance 
of $\mathrm{N}_{2} \mathrm{O}$ for ozone depletion when they argued that $\mathrm{N}_{2} \mathrm{O}$ is now the single most important anthropogenic ODS compared with those regulated by the Montreal Protocol and its amendments. This result is subsequently supported by Portmann et al. (2012) and Revell et al. (2012a, b), which discussed the importance of $\mathrm{N}_{2} \mathrm{O}$ to ozone depletion through the 21st century.

$\mathrm{N}_{2} \mathrm{O}$ affects ozone predominantly through $\mathrm{NO}_{\mathrm{x}}$-catalysed $\left(\mathrm{NO}_{\mathrm{x}}=\mathrm{NO}+\mathrm{NO}_{2}\right)$ ozone-loss cycles in the stratosphere (Crutzen and Ehhalt, 1977). $\mathrm{NO}_{\mathrm{x}}$ can be oxidized to nonradical species of $\mathrm{NO}_{\mathrm{y}}\left(\mathrm{NO}_{\mathrm{y}}=\mathrm{NO}_{\mathrm{x}}+\mathrm{NO}_{3}+\mathrm{HNO}_{3}+\right.$ $\left.\mathrm{HO}_{2} \mathrm{NO}_{2}+\mathrm{ClONO}_{2}+2 \mathrm{~N}_{2} \mathrm{O}_{5}+\mathrm{BrONO}_{2}\right)$, that act as the reservoirs of $\mathrm{NO}_{\mathrm{x}}$ and can also be converted back to $\mathrm{NO}_{\mathrm{x}}$. The fraction of $\mathrm{NO}_{\mathrm{y}}$ present as $\mathrm{NO}_{\mathrm{x}}$, therefore, dominates the $\mathrm{NO}_{\mathrm{x}}$-catalysed ozone-loss rate. This ratio of $\mathrm{NO}_{\mathrm{x}} / \mathrm{NO}_{\mathrm{y}}$, and hence the effect of $\mathrm{NO}_{\mathrm{x}}$ on stratospheric ozone, is moderated by other chemical processes, e.g. chlorine-catalysed ozone-loss cycles (Ravishankara et al., 2009).

On the other hand, since the loss of ozone is inversely related to local temperature changes throughout most of the stratosphere, the effect of $\mathrm{N}_{2} \mathrm{O}$ on the ozone layer is also modulated by the radiative cooling caused by other greenhouse gases (GHGs) such as carbon dioxide $\left(\mathrm{CO}_{2}\right)$ (Rosenfield et al., 2002; Chipperfield, 2009; Wuebbles, 2009; Dameris, 2010). The ozone depletion efficiency of $\mathrm{N}_{2} \mathrm{O}$ is expected to decrease in the stratosphere due to projected increases in $\mathrm{CO}_{2}$ (Rosenfield and Douglass, 1998). Some other studies argued that $\mathrm{CO}_{2}$-induced cooling could cause stratospheric ozone to recover to values greater than 1980 levels during this century (Chipperfield, 2009; Wuebbles, 2009) and lead to a so-called "super recovery". Fleming et al. (2011) further carried out a comprehensive study of longterm stratospheric effects of some source gases, including $\mathrm{N}_{2} \mathrm{O}$ and $\mathrm{CO}_{2}$, through a series of two-dimensional (2-D) chemistry-climate model simulations. They predicted that in the latter half of the 21st century, $\mathrm{CO}_{2}, \mathrm{~N}_{2} \mathrm{O}$, and methane $\left(\mathrm{CH}_{4}\right)$ loading will all have significant impacts on global total ozone, where the effect of $\mathrm{CO}_{2}$ changes on global total ozone has twice the magnitude of the effect of $\mathrm{N}_{2} \mathrm{O}$ changes.

Ozone depletion potential (ODP) is widely used in quantifying the relative ozone-destroying capabilities of compounds. ODP is defined as the time-integrated global ozone depletion induced by a unit mass emission of gas $\mathrm{X}$ relative to the same amount of emission of CFC-11 (Ravishankara et al., 2009). Ravishankara et al. (2009) highlighted that the ODP value of $\mathrm{N}_{2} \mathrm{O}$ is influenced more by chlorine concentration conditions than other factors, such as odd hydrogen, bromine and methane levels. However, other studies have shown that the effects of $\mathrm{N}_{2} \mathrm{O}$ on ozone depend on both the $\mathrm{CO}_{2}$ induced cooling and the chemical effects of $\mathrm{CH}_{4}$ (Portmann et al., 2012; Revell et al., 2012b).

Although those previous studies have investigated the impact of $\mathrm{N}_{2} \mathrm{O}$ on ozone depletion, the relative importance of the radiative and chemical effects of $\mathrm{N}_{2} \mathrm{O}$ remain unclear and the net effect of increased $\mathrm{N}_{2} \mathrm{O}$ on the ozone layer in a chang- ing climate is still under debate. Previous studies have mostly been based on mechanistic analysis, with the main focus being the chemical effect of $\mathrm{N}_{2} \mathrm{O}$ (Ravishankara et al., 2009), or have used relatively simple 2-D chemical-dynamical models (e.g. Portmann and Solomon, 2007; Chipperfield, 2009; Fleming et al., 2011) to diagnose the effect of $\mathrm{N}_{2} \mathrm{O}$ changes on the ozone layer. In this study, we re-examine the effect of $\mathrm{N}_{2} \mathrm{O}$ increases on ozone using a fully coupled threedimensional (3-D) chemistry-climate model (CCM). We attempt to clarify quantitatively the radiative and chemical effects of $\mathrm{N}_{2} \mathrm{O}$ increases on the ozone layer, and to diagnose the ozone changes in a changing climate when $\mathrm{CO}_{2}$ and $\mathrm{N}_{2} \mathrm{O}$ are both increasing. The ODP value of $\mathrm{N}_{2} \mathrm{O}$, as well as its dependence on present and future climate with increasing $\mathrm{CO}_{2}$ conditions, is also analysed.

The details of the model and numerical experiments are given in Sect. 2. The effect of $\mathrm{N}_{2} \mathrm{O}$ increases on ozone depletion under different scenarios, as well as its climate feedbacks, are addressed in Sect. 3. In Sect. 4, we analyse the contributions of various factors associated with $\mathrm{N}_{2} \mathrm{O}$ increases in modulating ozone depletion. The $\mathrm{N}_{2} \mathrm{O}$ ODP and its dependence on the temperature, $\mathrm{N}_{2} \mathrm{O}$, and $\mathrm{CO}_{2}$ values are discussed in Sect. 5. Conclusions and a discussion are presented in Sect. 6.

\section{Models and numerical experiments}

We have used a fully coupled CCM, the Whole Atmosphere Community Climate Model 3 (WACCM3) to investigate the chemical and thermal-dynamical responses to a linear future increase in $\mathrm{N}_{2} \mathrm{O}$. WACCM3 has 66 vertical levels from the ground to $4.5 \times 10^{-6} \mathrm{hPa}$ (approximately $145 \mathrm{~km}$ geometric altitude) with detailed interactive chemistry (Garcia et al., 2007) and a finite volume dynamical core (Lin, 2004). For this study, the simulations were carried out at $4^{\circ} \times 5^{\circ}$ horizontal resolution. The WACCM3 chemistry module is derived from the 3-D chemical transport Model for Ozone and Related chemical Tracers (MOZART) (Brasseur and Hitchman, 1988; Hauglustaine et al., 1998; Horowitz et al., 2003). More details about the WACCM3 model can be found in Garcia et al. (2007).

Four long-term WACCM simulations were performed in this study and detailed configurations of these simulations are listed in Table 1. The surface volume mixing ratios (vmr's) of GHGs in the control run (E0) are taken from the IPCC A1B scenario. In runs $\mathrm{E} 1$ and $\mathrm{E} 2$, the surface vmr's of $\mathrm{N}_{2} \mathrm{O}$ were increased linearly from $344 \mathrm{ppbv}$ in the year 2000 to 517 and $688 \mathrm{ppbv}$ in 2050 , respectively, which is $50 \%$ and $100 \%$ more than the $\mathrm{N}_{2} \mathrm{O}$ value in the year 2050 in the $\mathrm{A} 1 \mathrm{~B}$ scenario. This approach makes the $\mathrm{N}_{2} \mathrm{O}$ variation in our simulations similar to that in the A1B scenario during the first half of the simulations (with small additional increases in each year compared to the A1B scenario), but very different from the A1B scenario during the later half of the simula- 
Table 1. The configurations of four CCM transient simulations.

\begin{tabular}{cl}
\hline Experiments & GHG scenario \\
\hline E0 & IPCC A1B scenario, the $\mathrm{N}_{2} \mathrm{O}$ surface vmr is about $316 \mathrm{ppbv}$ in 2000 and 344 ppbv in 2050 \\
E1 & $\mathrm{N}_{2} \mathrm{O}$ surface vmr increased linearly from $316 \mathrm{ppbv}$ in 2000 to $517 \mathrm{ppbv}$ in 2050 \\
E2 & $\mathrm{N}_{2} \mathrm{O}$ surface vmr increased linearly from $316 \mathrm{ppbv}$ in 2000 to $688 \mathrm{ppbv}$ in 2050 \\
E3 & As E1 with additional linear increase in $\mathrm{CO}_{2} \mathrm{vmr}$ from 370 ppmv in 2000 to 780 ppmv in 2050 \\
\hline
\end{tabular}

Table 2. The configurations of four CCM sensitivity simulations.

\begin{tabular}{cl}
\hline Simulations & GHG settings \\
\hline S0 & Fix $\mathrm{N}_{2} \mathrm{O}$ as 2050 climatology in IPCC A1B scenario \\
S1 & Increase $\mathrm{N}_{2} \mathrm{O}$ by $50 \%$ on $\mathrm{S} 0$ only in chemistry \\
$\mathrm{S} 2$ & Increase $\mathrm{N}_{2} \mathrm{O}$ by $50 \%$ on $\mathrm{S} 0$ only in radiation \\
$\mathrm{S} 3$ & Increase $\mathrm{N}_{2} \mathrm{O}$ by $50 \%$ on $\mathrm{S} 0$ interactively \\
$\mathrm{S} 4$ & Increase $\mathrm{CFC}-11$ by $10 \%$ on S0 interactively \\
\hline
\end{tabular}

tions where we have a much stronger $\mathrm{N}_{2} \mathrm{O}$ increase, for the purpose of amplifying response signals of the atmosphere. In run $\mathrm{E} 3$, both $\mathrm{N}_{2} \mathrm{O}$ and $\mathrm{CO}_{2}$ were increased linearly in time from 2001 and increased by $50 \%$ in 2050, with a rate of increase of $1 \% \mathrm{yr}^{-1}$. More details about the configurations of the simulations are listed in Table 1 . The sea surface temperature (SST) and sea ice fields used in the four runs are the same (HadGEM1) and are derived from the SST and sea ice fields prepared for the Chemistry-Climate Model Validation activity 2 (CCMVal-2) REF-B2 simulations (Eyring et al., 2008; Morgenstern et al., 2010) for the period 2001 to 2050.

To estimate the ODP value of $\mathrm{N}_{2} \mathrm{O}$, three WACCM timeslice simulations were performed. In the first simulation (S0), GHG loadings were based on the IPCC A1B scenario and fixed in the year 2050. In simulations $\mathrm{S} 1$ and $\mathrm{S} 4, \mathrm{~N}_{2} \mathrm{O}$ and CFC -11 concentrations were increased by $10 \%$ and $50 \%$ relative to that in simulation $\mathrm{S} 0$, respectively. To separate the radiative and chemical effects of increasing $\mathrm{N}_{2} \mathrm{O}$ on stratospheric ozone, two extra simulations were performed. In simulations $\mathrm{S} 2$ and $\mathrm{S} 3$, the mixing ratios of $\mathrm{N}_{2} \mathrm{O}$ were increased as in $\mathrm{S} 1$, but only in the model's chemistry and radiation schemes, respectively. The $\mathrm{N}_{2} \mathrm{O}$ in $\mathrm{S} 1$ were increased in both the chemistry and radiation schemes. Detailed configurations of all sensitivity simulations are given in Table 2 . All of these sensitivity simulations used 12 months SST and sea ice climatologies derived from observed monthly mean values for the time period from 1996 to 2000 (Rayner et al., 2003).

\section{Modelled ozone depletion by $\mathbf{N}_{2} \mathrm{O}$}

\subsection{Future $\mathrm{NO}_{\mathrm{x}}$ and $\mathrm{NO}_{\mathrm{y}}$ in changing climate}

In the middle and upper stratosphere, $\mathrm{N}_{2} \mathrm{O}$ decomposes by photolysis or by reactions with $\mathrm{O}\left({ }^{1} \mathrm{D}\right)$ :

$$
\begin{aligned}
& \mathrm{N}_{2} \mathrm{O}+h v \rightarrow \mathrm{N}_{2}+\mathrm{O} \\
& \mathrm{N}_{2} \mathrm{O}+\mathrm{O}\left({ }^{1} \mathrm{D}\right) \rightarrow \mathrm{N}_{2}+\mathrm{O}_{2} \\
& \mathrm{~N}_{2} \mathrm{O}+\mathrm{O}\left({ }^{1} \mathrm{D}\right) \rightarrow 2 \mathrm{NO} .
\end{aligned}
$$

Only the minor channel of $\mathrm{R} 3$ leads to $\mathrm{NO}_{\mathrm{y}}$ production. $\mathrm{NO}_{\mathrm{y}}$ is removed from the stratosphere by transport to the troposphere and eventual washout, or by local photochemical loss at high altitudes via:

$\mathrm{N}+\mathrm{NO} \rightarrow \mathrm{N}_{2}+\mathrm{O} \quad k_{4}=2.1 \times 10^{-11} \exp (+100 / T)$.

The abundance of $\mathrm{N}$ is determined by photolysis of $\mathrm{NO}$ and by the reaction:

$\mathrm{N}+\mathrm{O}_{2} \rightarrow \mathrm{NO}+\mathrm{O}_{2} \quad k_{5}=1.5 \times 10^{-11} \exp (-3600 / T)$.

The reaction rates for $\mathrm{R} 4$ and $\mathrm{R} 5$ are taken from Sander et al. (2006). Because of the temperature dependence of the reactions controlling the chemical loss of $\mathrm{NO}_{\mathrm{y}}$, the net $\mathrm{NO}_{\mathrm{y}}$ yield rate tends to decrease in a future cooler stratosphere, as R4 speeds up while R5 slows down (Rosenfield and Douglass, 1998). Without significant stratospheric cooling, $\mathrm{N}_{2} \mathrm{O}$ increases in the atmosphere will cause $\mathrm{NO}_{\mathrm{y}}$ and $\mathrm{NO}_{\mathrm{x}}$ to increase in the stratosphere. Figure 1 shows the time series of the global mean $\mathrm{NO}_{\mathrm{x}}$ and $\mathrm{NO}_{\mathrm{y}}$ fields from the four experiments, and corresponding changes in the global mean column $\mathrm{NO}_{\mathrm{x}}$ and $\mathrm{NO}_{\mathrm{y}}$ in runs E1, E2 and E3, relative to that in the control run E0. Note that a $100 \%$ increase in $\mathrm{N}_{2} \mathrm{O}$ by the end of 2050 causes an increase in the global mean column $\mathrm{NO}_{\mathrm{y}}$ and $\mathrm{NO}_{\mathrm{x}}$ by $12 \times 10^{15}$ molecules $\mathrm{cm}^{-2}$ and $4 \times 10^{15}$ molecules $\mathrm{cm}^{-2}$, respectively. However, when $\mathrm{CO}_{2}$ is also increased by $50 \%$ in conjunction with a $50 \%$ $\mathrm{N}_{2} \mathrm{O}$ increase at the end of 2050 in run E3 (implying a cooler stratosphere than that in run E1, in which only $\mathrm{N}_{2} \mathrm{O}$ is increased by $50 \%$ at the end of 2050), the $\mathrm{NO}_{\mathrm{y}}$ and $\mathrm{NO}_{\mathrm{x}}$ increases are smaller than those in run E1 (Fig. 1a and c). These results imply that the total ozone depletion effects for $\mathrm{N}_{2} \mathrm{O}$ in a future climate will actually depend both on stratospheric temperature changes and tropospheric $\mathrm{N}_{2} \mathrm{O}$ changes, which have opposite effects on ozone in the middle and upper stratosphere. 
(a) Global Mean Column NOy

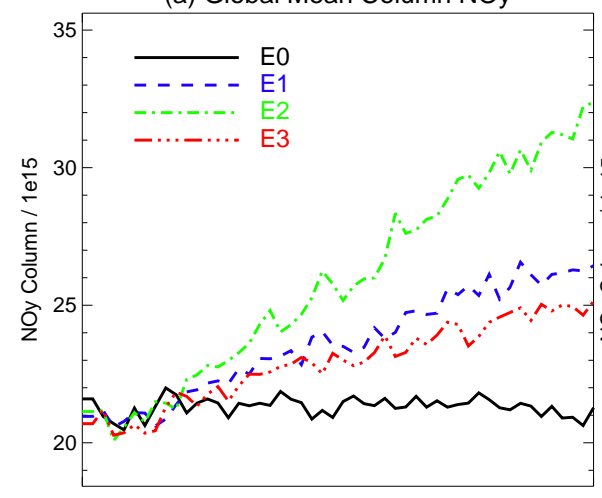

(c) Global Mean NOy Column Change

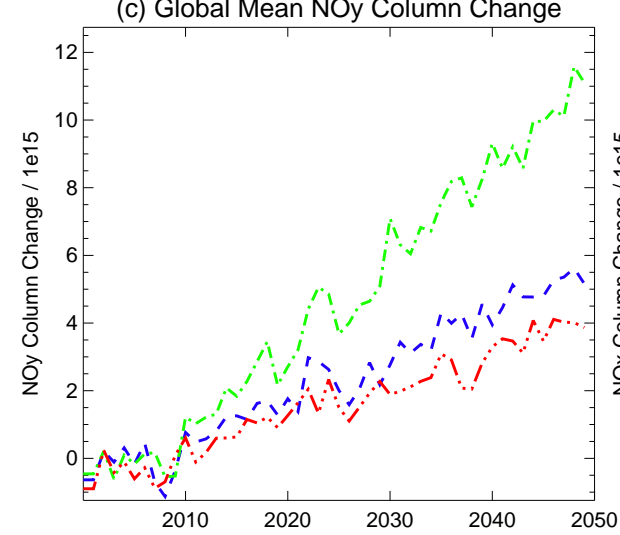

(b) Global Mean Column NOx

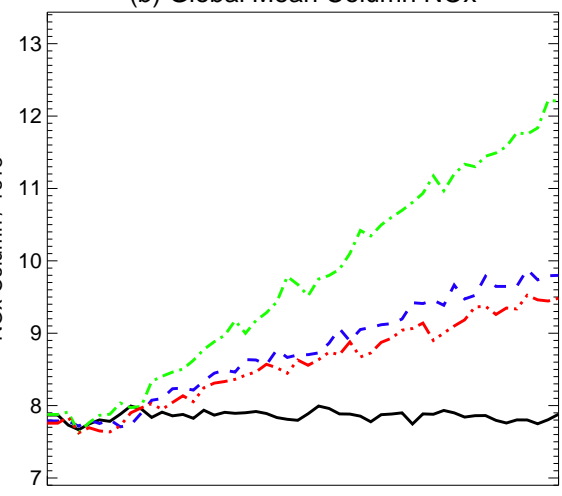

(d) Global Mean NOx Column Change

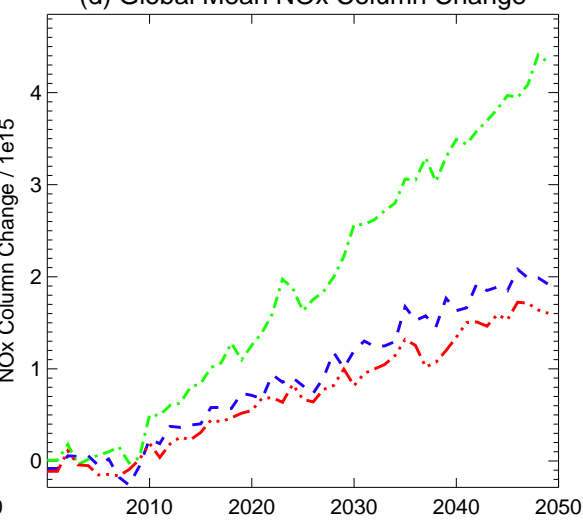

Figure 1. Time series of global mean (a) column $\mathrm{NO}_{\mathrm{y}}\left(\right.$ molecules $\mathrm{cm}^{-2}$ ) and (b) column $\mathrm{NO}_{\mathrm{x}}\left(\right.$ molecules cm ${ }^{-2}$ ) in E0 (black line), E1 (blue line), E2 (green line) and E3 (red line). Difference in (c) column $\mathrm{NO}_{\mathrm{y}}$ and (d) column $\mathrm{NO}_{\mathrm{x}}$ between E1 and E0 (blue line), E2 and E0 (green line), E3 and E0 (red line).

\subsection{Ozone responses to $\mathrm{N}_{2} \mathrm{O}$ changes}

Figure 2 shows percent changes of ozone mixing ratios and TCO caused by $\mathrm{N}_{2} \mathrm{O}$ increases in runs E1, E2 and E3 relative to the control run E0. These ozone mixing ratio and TCO changes are calculated from the ozone climatologies of the final 10 years (2041-2050) of the model output from runs E1, E2, E3 and E0. It is apparent from Fig. 2 that the ozone changes have large spatial and temporal variations. The strongest ozone depletion can be found in the middle and upper stratosphere, with a 6-10\% decrease of ozone when $\mathrm{N}_{2} \mathrm{O}$ is increased by $50-100 \%$ (Fig. $2 \mathrm{a}$ and b), and the largest decrease of ozone in the middle and upper stratosphere appears in the Arctic region. The result here is consistent with previous studies (Ravishankara et al., 2009; Daniel et al., 2010), which indicated that $\mathrm{N}_{2} \mathrm{O}$ has a large contribution to ozone depletion just above the region where ozone concentrations are largest (around $10 \mathrm{hPa}$ ).

In the lower stratosphere, increased $\mathrm{N}_{2} \mathrm{O}$ could reduce the efficiency of $\mathrm{Cl}_{\mathrm{y}}$ and $\mathrm{Br}_{\mathrm{y}}$ for ozone destruction, by tying up more of these halogens in the $\mathrm{ClONO}_{2}$ and $\mathrm{BrONO}_{2}$ reservoir species, consequently, $\mathrm{N}_{2} \mathrm{O}$ increases lead to more ozone. On the other hand, in the lower stratosphere/upper tro- posphere, UV radiation is enhanced due to the ozone reduction in the middle and upper stratosphere, resulting in more ozone production through the so-called "self-healing" effect. These two effects lead to an increase of ozone in the lower stratosphere/upper troposphere, which is evident in Fig. 2. A notable feature in Fig. 2 is that ozone increases in the lower stratosphere/upper troposphere can be seen mostly in Southern Hemisphere mid-latitudes. This feature is slightly different from the result of Ravishankara et al. (2009), which showed that the "self-healing" effect is most significant in the tropics. Below $100 \mathrm{hPa}$ in the troposphere, $\mathrm{N}_{2} \mathrm{O}$ increases result in more ozone with a maximum $10 \%$ increase at southern high latitudes when $\mathrm{N}_{2} \mathrm{O}$ is increased by $100 \%$ from 2001 to 2050 (Fig. 2b).

Figure 2c also indicates the destruction of ozone associated with $\mathrm{N}_{2} \mathrm{O}$ increases in run E3 is small relative to that in runs E1, particularly in the middle and upper stratosphere, consistent with the previous finding that $\mathrm{CO}_{2}$-induced cooling tends to increase ozone in the future (e.g. Haigh and Pyle, 1982; Shepherd, 2008; Chipperfield, 2009; Wuebbles, 2009; Oman et al., 2010a) by slowing down the gas-phase chemical reactions associated with catalytic ozone destruction. 

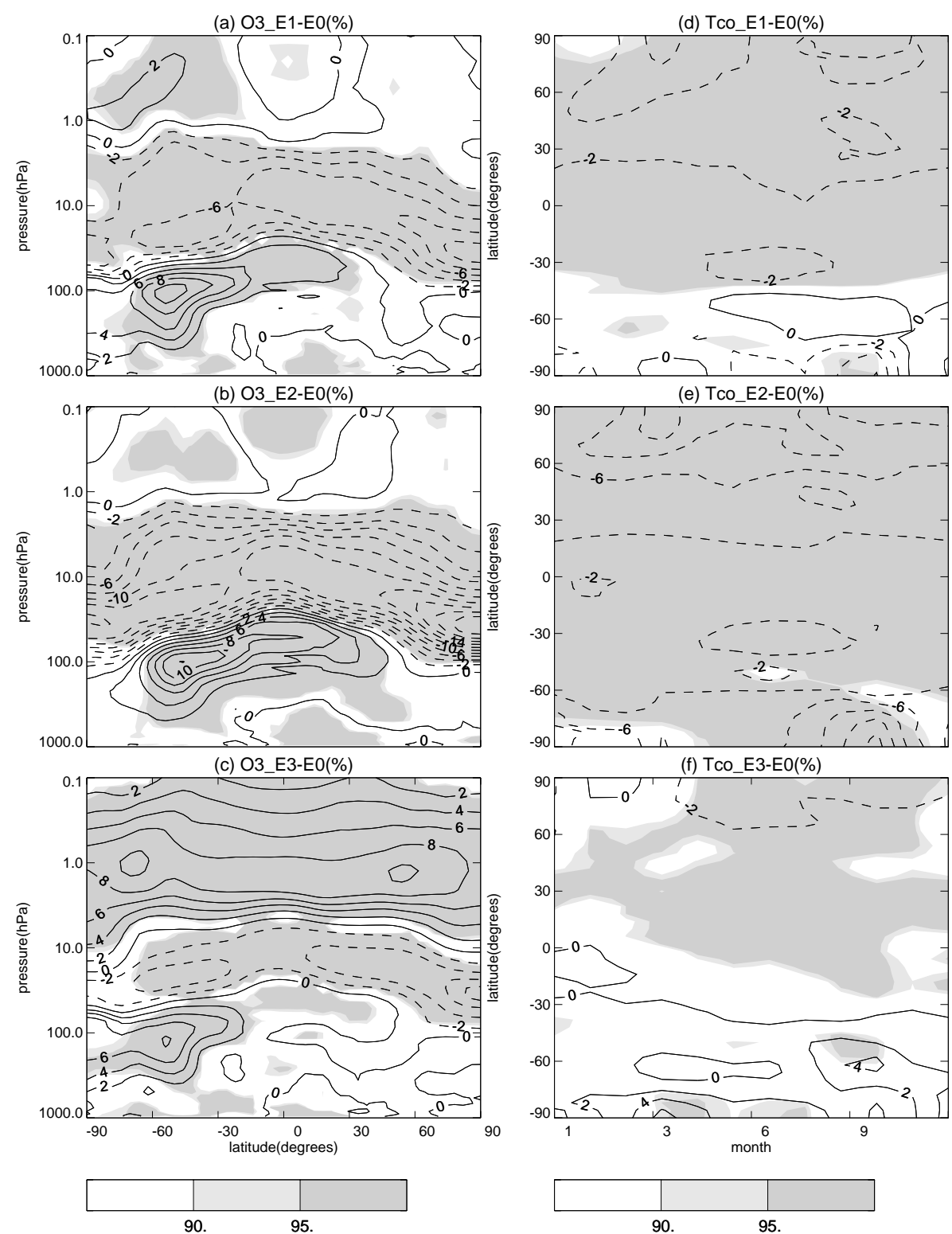

Figure 2. Latitude-pressure cross sections of differences (\%) in zonal mean ozone mixing ratios (2041-2050) between WACCM experiments (a) E1 and E0, (b) E2 and E0, and (c) E3 and E0. Time-latitude cross sections of differences (\%) in zonal mean total column ozone climatology (2041-2050) between experiments (d) E1 and E0, and (e) E2 and E0, (f) E3 and E0. The percentage is the ratio of the ozone and TCO changes (E1, E2 and E3 minus E0) referenced to the run E0. The contour interval is $2 \%$ for percentage ozone changes. The grey colours represent significance levels for the mean state differences between different experiments by Student's $t$ test.

Due to the significant ozone reduction in the middle and upper stratosphere caused by increased $\mathrm{N}_{2} \mathrm{O}$, the TCO in the two WACCM simulations (E1 and E2) decreases compared with that in the control run, E0 (Fig. 2d and e), particularly at high latitudes. A $50 \% \mathrm{~N}_{2} \mathrm{O}$ increase causes a maximum $6 \%$ TCO decrease (Fig. 2d) over the final 10 years of the simulation. When $\mathrm{N}_{2} \mathrm{O}$ is increased by $100 \%$ in run E2, TCO changes become larger with a maximum decrease of $10 \%$ at high latitudes. The combined effect of $\mathrm{N}_{2} \mathrm{O}$ and $\mathrm{CO}_{2}$ increases result in a slight TCO decrease (1-2\%) in the North- ern Hemisphere, but a significant increase of (2-6\%) in the Southern Hemisphere (Fig. 1f) over the final 10 years of the simulation, due to the offsetting impact of $\mathrm{CO}_{2}$-induced cooling.

Figure 3a-c show modelled ozone linear trends (20012050) as a function of latitude and pressure under different prescribed $\mathrm{N}_{2} \mathrm{O}$ changes. Also shown are the time series of TCO averaged over different latitude bands, i.e. $90^{\circ} \mathrm{N}-$ $70^{\circ} \mathrm{N}, 22^{\circ} \mathrm{S}-22^{\circ} \mathrm{N}$, and $70^{\circ} \mathrm{S}-90^{\circ} \mathrm{S}$. Consistent with previous studies (e.g. Tian and Chipperfield, 2005; Austin and 

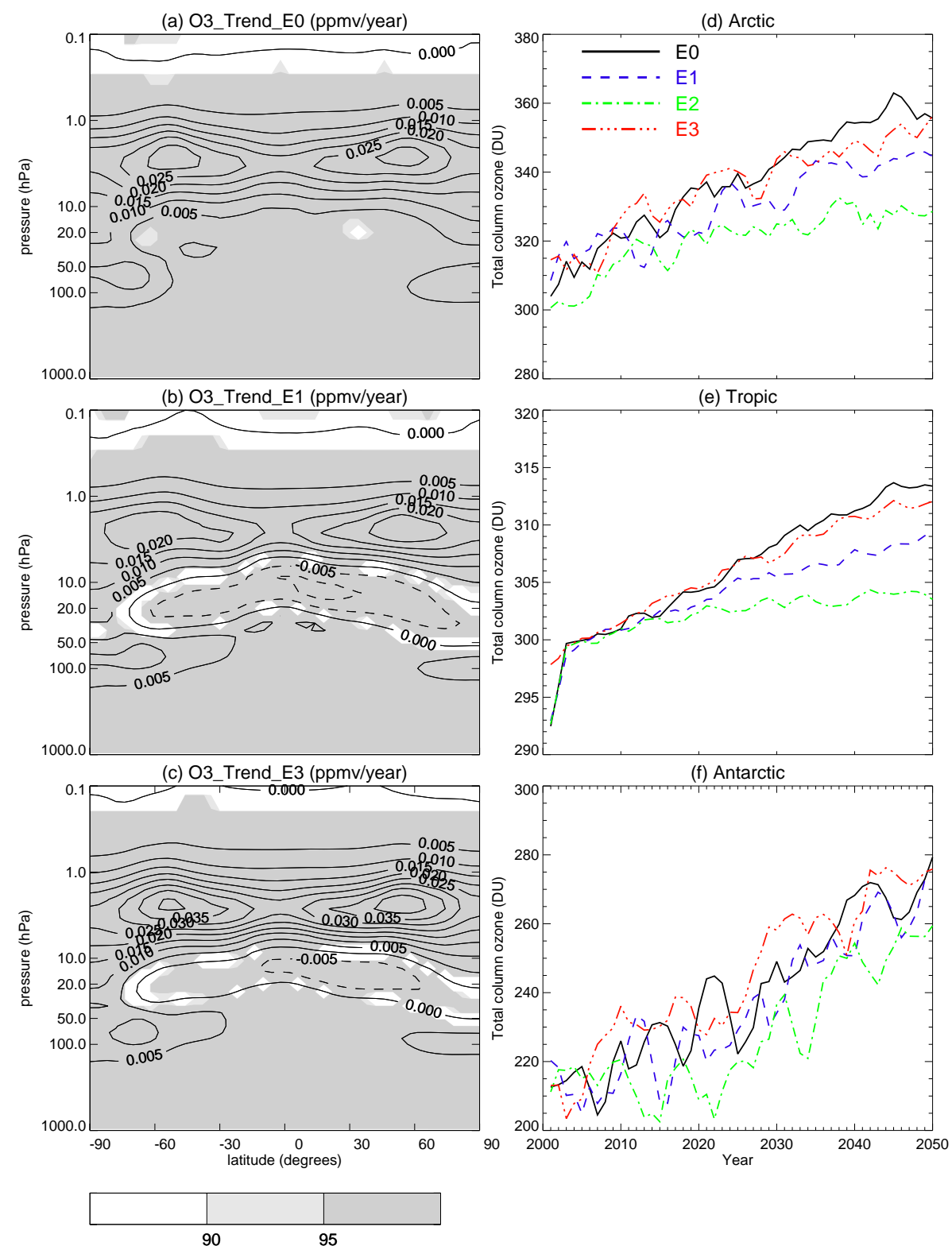

Figure 3. (a, b, c) Latitude-pressure cross sections of the long-term (2001-2050) trends of zonal mean ozone mixing ratios (ppmv yr ${ }^{-1}$ ) in WACCM experiments E0, E1 and E3. The contour interval is $0.005 \mathrm{ppmv} \mathrm{yr}^{-1}$. Grey colours represent statistic significance levels of the trends. (d, e, f) Time series of TCO in different regions (Arctic, Tropics, Antarctic) in experiments E0 (black line), E1 (blue dashed line), E2 (green dashed-dotted line) and E3 (red dashed-dotted line). To make the lines easily identified, the time series has been smoothed by nine-point smoothing.

Wilson, 2006; Newman et al., 2006; Eyring et al., 2007; WMO, 2007), the global ozone will generally recover in the next half century under the IPCC A1B GHG scenario, with a maximum increasing trend of $0.3 \mathrm{ppmv} / 10 \mathrm{yr}$ at $10-1 \mathrm{hPa}$ (Fig. 3a). However, if $\mathrm{N}_{2} \mathrm{O}$ is further increased by $50 \%$ relative to the IPCC A1B projection, the ozone in the middle stratosphere at around $20 \mathrm{hPa}$ decreases with a maximum trend of $-0.2 \mathrm{ppmv} / 10 \mathrm{yr}$ from 2001 to 2050 , although the ozone in the upper stratosphere still increases (Fig. 3b). Note that a steadily declining trend in future ozone in the tropical lower stratosphere was found in previous studies (Oman et al., 2010a; SPARC-CCMVal, 2010; Eyring et al., 2010a), while there is no significant ozone trend in the tropical lower stratosphere in our simulations through 2050. A possible reason is that the upwelling in our $50 \mathrm{yr}$ simulations has no significant trend in the lower stratosphere/upper troposphere (Table 3), though we used an increased GHG scenario and time varying SSTs. A more detailed discussion of 
Table 3. The tropical $\left(25^{\circ} \mathrm{N}-25^{\circ} \mathrm{S}\right)$ upwelling $\left(w^{*}\right)$ averaged between 70 and $20 \mathrm{hPa}$ over the last $10 \mathrm{yr}$ of the four simulations, and changes in $w^{*}\left(\Delta w^{*}\right)$ relative to the first $10 \mathrm{yr}$ of the corresponding simulations.

\begin{tabular}{ccc}
\hline Experiments & $w^{*}\left(10^{-3} \mathrm{~ms}^{-1}\right)$ & $\Delta w^{*}(\%)$ \\
\hline E0 & 0.029 & 5.5 \\
E1 & 0.032 & 28.4 \\
E2 & 0.037 & 37.3 \\
E3 & 0.033 & 21.9 \\
\hline
\end{tabular}

the upwelling changes in three simulations will be given in Sect. 3.3.

As in Fig. 1, $\mathrm{CO}_{2}$ increases tend to offset the effect of $\mathrm{N}_{2} \mathrm{O}$ on ozone trends in the middle stratosphere (Fig. 3c). When $\mathrm{N}_{2} \mathrm{O}$ and $\mathrm{CO}_{2}$ are both increased by $50 \%$, the declining trend of ozone in the middle stratosphere becomes less significant. It is worth noting that the effect of increased $\mathrm{N}_{2} \mathrm{O}$ on longterm trends of ozone mixing ratios from 2001 to 2050 at about $20-10 \mathrm{hPa}$ has evident spatial variations. Ozone mixing ratios decrease most significantly in the tropical middle stratosphere with a trend up to $-0.1 \mathrm{ppmv} / 10 \mathrm{yr}$ when $\mathrm{N}_{2} \mathrm{O}$ is increased by $50 \% . \mathrm{N}_{2} \mathrm{O}$ increases have no significant effect on ozone trends in the Antarctic middle stratosphere, but tend to slow down the ozone increase in the Arctic stratosphere. Previous studies also found that ozone evolution over the Antarctic shows small sensitivity to GHG changes (Eyring et al., 2010a). Similar features can be noted in the TCO time series shown in Fig. 3d-f. Figure 3 also indicates that the higher $\mathrm{N}_{2} \mathrm{O}$ corresponds to a less significant increasing trend of ozone, implying that increased $\mathrm{N}_{2} \mathrm{O}$ overall tends to cause more ozone destruction.

To understand the hemispheric asymmetry of ozone trends in the middle stratosphere exhibited in Fig. 3, Fig. 4 shows the time series of ozone mixing ratios from 2001 to 2050, averaged over different latitude bands between 20 and $10 \mathrm{hPa}$. It is apparent that the effect of $\mathrm{N}_{2} \mathrm{O}$ increases on ozone at $20-10 \mathrm{hPa}$ is more significant in the Arctic and in the tropics than in the Antarctic. Meanwhile, the decline of ozone in E1 and E2 in the tropics is stronger than that in the Arctic. Also shown are the corresponding time series of the reactive chlorine $\left(\mathrm{ClO}_{\mathrm{x}}, \mathrm{ClO}_{\mathrm{x}}=\mathrm{Cl}+\mathrm{ClO}+2 \mathrm{Cl}_{2} \mathrm{O}_{2}\right)$. In all the simulations $\mathrm{ClO}_{\mathrm{x}}$ tends to decrease in response to the decreasing chlorine loading that is imposed by prescribed surface halocarbon mixing ratios. However, due to the interconnection between the $\mathrm{NO}_{\mathrm{x}}$-catalysed and $\mathrm{ClO}_{\mathrm{x}}$-catalysed ozone-loss cycles, the rates of $\mathrm{ClO}_{\mathrm{x}}$ decline vary with different $\mathrm{N}_{2} \mathrm{O}$ abundances in different experiments. A further examination of the modelled $\mathrm{NO}_{\mathrm{x}}$ fields reveals that $\mathrm{NO}_{\mathrm{x}}$ concentrations in the Antarctic stratosphere are lower than those in the Arctic stratosphere (not shown), and the differences become larger when the $\mathrm{N}_{2} \mathrm{O}$ increase is changed from $50 \%$ to $100 \%$. The above analysis indicates that the chemical ef- fect of $\mathrm{N}_{2} \mathrm{O}$ increases on ozone depletion is more significant in the Arctic than in the Antarctic.

\subsection{Thermal-dynamical feedbacks associated with $\mathrm{N}_{2} \mathrm{O}$ increases}

The effect of $\mathrm{N}_{2} \mathrm{O}$ increases on ozone in the tropical stratosphere is not only related to chemical processes. Austin et al. (2010a) pointed out that the strengthened Brewer-Dobson (BD) circulation in the future climate could lead to ozone decreases in the tropical lower stratosphere as a result of intensified upward transport of ozone-poor air from below. Table 3 lists the tropical $\left(25^{\circ} \mathrm{N}-25^{\circ} \mathrm{S}\right)$ upwelling $\left(w^{*}\right)$ at 70 $20 \mathrm{hPa}$ averaged over the last $10 \mathrm{yr}$ of the four WACCM experiments, and its change $\left(\delta w^{*}\right)$ relative to the result of the first $10 \mathrm{yr}$ of simulations. It is apparent that the tropical upwelling increases with increased GHGs. However, one can see that relative changes of $w^{*}$ between the first and last decade of the simulations do not vary simply with GHG loading. In the experiment with both $\mathrm{N}_{2} \mathrm{O}$ and $\mathrm{CO}_{2}$ increases (run E3), $\delta w^{*}$ is not even the largest. This is consistent with the result in Xie et al. (2008), which showed that without SST increases associated with increasing GHGs, the change in the tropical upwelling is not significant.

As mentioned above, previous studies have shown that the tropical upwelling will increase in a warming climate (SPARC-CCMVal, 2010, and references therein). However, in our control run E0, the increasing trend of the tropical upwelling is not significant. Consequently, the ozone decline in the tropical lower stratosphere is rather weak (Fig. 3a). As SST increases contribute a large part to the strengthening of the BD circulation in the lower stratosphere (Oberländer et al., 2013), the insignificant trend in the tropical upwelling in run E0 may be owing to the relatively weak increasing trend in SSTs in our simulations. The SST and sea ice fields used in our simulations are HadGEM1 SST data prepared for the CCMVal-2 REF-B2 simulations (SPARC-CCMVal, 2010; Morgenstern et al., 2010). A comparison between the HadGEM1 SST data and the CCSM3 SST data (used widely in the CCM simulations in CCMval) reveals that the longterm increase of SSTs in the future century in the CCSM3 data is much stronger than that in the HadGEM1 data (not shown). This highlighted the uncertainties of the simulated trends of the BD circulation.

As a greenhouse gas, increasing $\mathrm{N}_{2} \mathrm{O}$ can directly warm the troposphere and can also influence stratospheric temperature through the direct radiative effect and the indirect radiative effect associated with ozone feedbacks. Figure 5 shows the modelled temperature changes caused by different $\mathrm{N}_{2} \mathrm{O}$ increases. A $50 \%$ increase of $\mathrm{N}_{2} \mathrm{O}$ causes a $1 \mathrm{~K}$ cooling in the northern middle stratosphere and a $2 \mathrm{~K}$ cooling above $1 \mathrm{hPa}$ at southern high latitudes (Fig. 5a). A $100 \%$ increase in $\mathrm{N}_{2} \mathrm{O}$ causes a cooling in most regions of the stratosphere, with a maximum $3 \mathrm{~K}$ cooling in the tropical middle stratosphere (Fig. 5b). By comparing Figs. 3 and 5, we can see that the im- 
(a) O3-Arctic
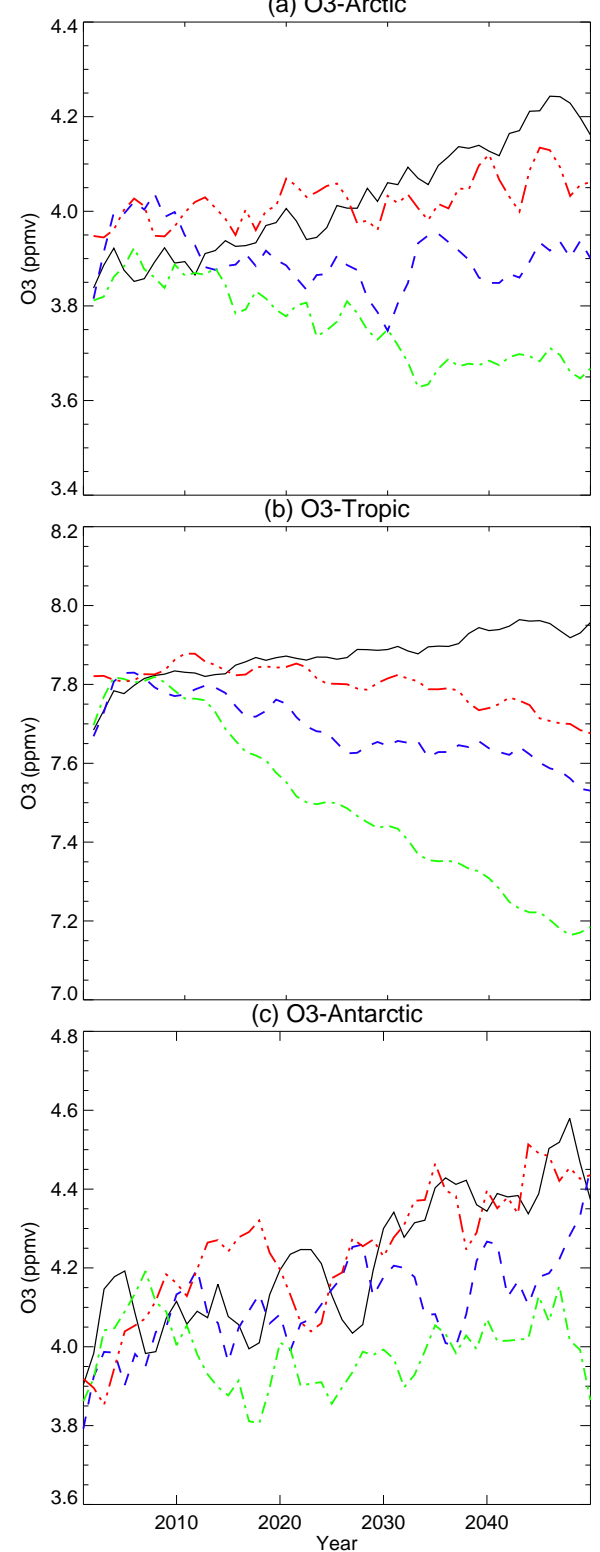

(d) $\mathrm{ClOx}$-Arctic

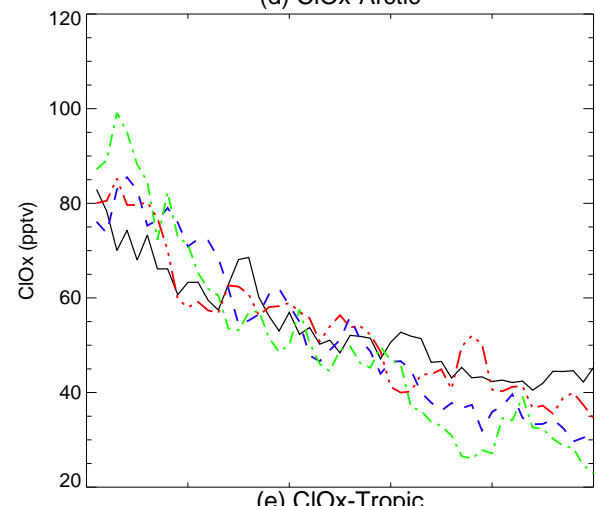

(e) 'ClOx-Tropic
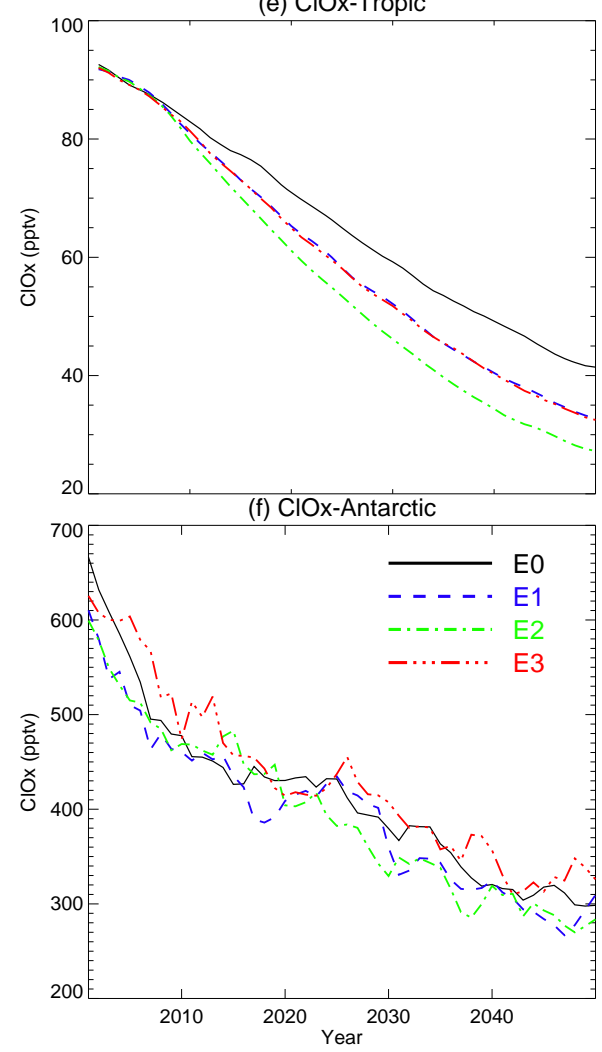

Figure 4. Time series of mean $(\mathbf{a}, \mathbf{b}, \mathbf{c})$ ozone and $(\mathbf{d}, \mathbf{e}, \mathbf{f}) \mathrm{Cl}_{\mathrm{X}}\left(\mathrm{Cl}_{\mathrm{X}}=\mathrm{Cl}+\mathrm{ClO}+2 \mathrm{Cl}_{2} \mathrm{O}_{2}\right)$ between 20 and $10 \mathrm{hPa}$ averaged over (a) Arctic $\left(60^{\circ} \mathrm{N}-90^{\circ} \mathrm{N}\right)$, (b) Tropics $\left(22^{\circ} \mathrm{N}-22^{\circ} \mathrm{S}\right)$ and (c) Antarctic $\left(60^{\circ} \mathrm{S}-90^{\circ} \mathrm{S}\right)$ in E0 (black line), E1 (blue line), E2 (green line) and E3 (red line). The time series has been smoothed by nine-point smoothing.

pact of $\mathrm{N}_{2} \mathrm{O}$ on stratospheric temperature is mainly caused by $\mathrm{N}_{2} \mathrm{O}$-induced ozone changes, rather than the direct radiative effect of $\mathrm{N}_{2} \mathrm{O}$. As expected, the cooling of the stratosphere becomes much larger when $\mathrm{CO}_{2}$ is also increased by $50 \%$ together with a $50 \% \mathrm{~N}_{2} \mathrm{O}$ increase (Fig. 5c).

As polar stratospheric clouds (PSCs) are closely related to ozone loss in the polar stratosphere (e.g. Rex et al., 2004; Chipperfield et al., 2005; Austin et al., 2010b), it is useful to examine the effect of $\mathrm{N}_{2} \mathrm{O}$ increases on the occurrence of PSCs. The surface area of PSCs, where temperatures are below $T_{P S C}$ (the NAT equilibrium temperature is estimated from water vapour, nitric acid $\left(\mathrm{HNO}_{3}\right)$ and temperature fields), is commonly used to analyse the variability of PSCs (WMO, 2007). Figure 6 shows the vertical distribution of the modelled changes in the PSC surface area during JJA in the Antarctic and DJF in the Arctic averaged over the final 10 years of the model simulations. The modelled PSC area is enlarged by $1-2 \times 10^{6} \mathrm{~km}^{2}$ in the Arctic between 200 and $20 \mathrm{hPa}$, when $\mathrm{N}_{2} \mathrm{O}$ is increased by $50-100 \%$. The PSC area changes caused by $\mathrm{N}_{2} \mathrm{O}$ increases are relatively large compared with the mean value of the PSC area in the Arctic, which is about $10 \times 10^{6} \mathrm{~km}^{2}$ between 200 and $20 \mathrm{hPa}$. In the 


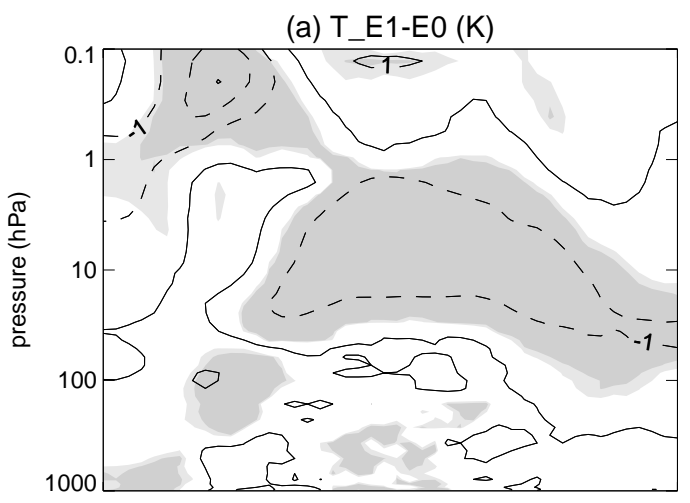

(b) T_E2-E0 (K)

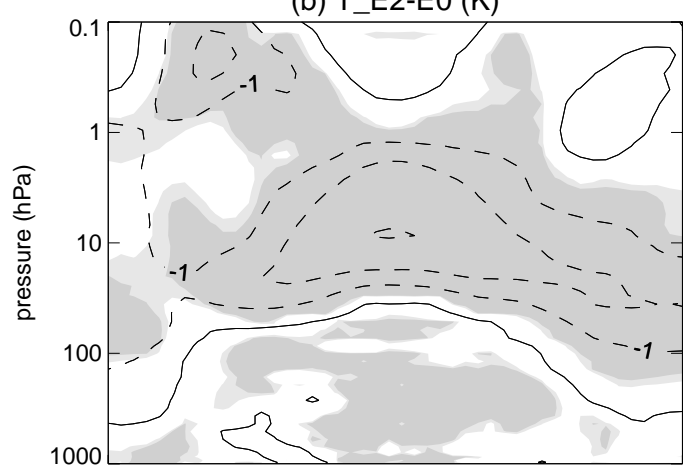

(c) T_E3-E0 (K)

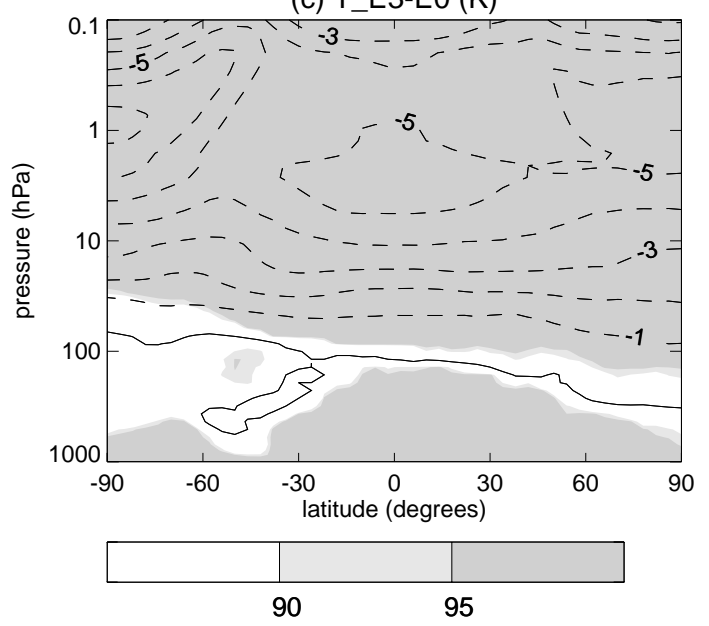

Figure 5. Latitude-pressure cross sections of differences in zonal mean temperature (2041-2050) between WACCM experiments (a) E1 and E0, (b) E2 and E0, and (c) E3 and E0. The contour interval is $1 \mathrm{~K}$. Grey colours represent statistical significance levels for the mean state differences between different experiments by Student's $t$ test.

Antarctic lower stratosphere, however, $\mathrm{N}_{2} \mathrm{O}$ increases cause only small changes in the modelled PSC area (the mean PSC area in the Antarctic is about $15 \times 10^{6} \mathrm{~km}^{2}$ ). An exception occurs in the Antarctic mid-stratosphere at about $10 \mathrm{hPa}$, at the upper limit of PSC occurrence, where additional cooling can cause more PSCs.
Figure 6 suggests that the $\mathrm{N}_{2} \mathrm{O}$ increases have different impacts on the modelled PSC area in the Arctic and Antarctic stratosphere. In the Arctic stratosphere, temperatures are close to the threshold for the widespread PSC formation, and the cooling caused by $\mathrm{N}_{2} \mathrm{O}$ increases can result in more PSCs. In the Antarctic lower stratosphere, temperatures in winter and spring are essentially always low enough for PSC formation. Therefore, a small cooling caused by $\mathrm{N}_{2} \mathrm{O}$ increases has no significant impact on PSC formation. The increased PSC area is also related to the concentration of $\mathrm{HNO}_{3}$, which is increased when $\mathrm{N}_{2} \mathrm{O}$ is increased. This difference in modelled PSC area changes between the Arctic and Antarctic makes a significant contribution to the hemispheric asymmetry of ozone destruction discussed in Fig. 3. However, previous studies (SPARC-CCMVal, 2010) show that the potential for chlorine activation ( $\mathrm{PACl}$, a measure similar to PSC volume) in the Arctic, simulated by WACCM, is overall larger than expected, though WACCM performs well for polar ozone depletion processes. This may lead to an overestimation of the ozone depleting effect of $\mathrm{N}_{2} \mathrm{O}$ increases in the Arctic. Also noticeable is that an additional $50 \% \mathrm{~N}_{2} \mathrm{O}$ increase (E2) causes a larger increase in PSC area in the Arctic than an additional $50 \% \mathrm{CO}_{2}$ increase (E3). Here the increased $\mathrm{NO}_{\mathrm{y}}$ from additional $\mathrm{N}_{2} \mathrm{O}$ promotes the formation of nitric acid trihydrate.

\section{Contributions to ozone depletion from different factors due to $\mathrm{N}_{2} \mathrm{O}$ changes}

The attribution of ozone variations to dynamical, radiative, and chemical effects resulting from changes in GHGs and ODSs is an important issue in stratospheric climate. Multiple linear regression (MLR) analysis is commonly used for this purpose (WMO, 2007; Shepherd, 2008; Stolarski et al., 2010; Oman et al., 2010b). For a given location and time, an ozone change $\left(\Delta \mathrm{O}_{3}\right)$ can be expressed as follows:

$\Delta \mathrm{O}_{3}(t)=\sum_{j} c_{j} \Delta X_{j}(t)+\varepsilon(t)$

where the variables $X_{j}$ are the factors that can affect ozone, the coefficients $c_{j}$ are the sensitivity of ozone to the factors $X_{j}$, and $\varepsilon$ is the error in the fit. The coefficients $c_{j}$ are determined through a least square minimization of $\varepsilon$. Here, $\Delta \mathrm{O}_{3}$ and $\Delta X_{j}$ are the changes in ozone and other quantities between different model experiments with respect to the control experiment (E0; i.e. $\Delta \mathrm{O}_{3}=\mathrm{O}_{3, \mathrm{E} 1}-\mathrm{O}_{3, \mathrm{E} 0}$, where $\mathrm{O}_{3, \mathrm{E} 1}$ and $\mathrm{O}_{3, \mathrm{E} 0}$ represent modelled ozone data from runs E0 and E1, respectively).

We select $\mathrm{NO}_{\mathrm{x}}, \mathrm{ClO}_{\mathrm{x}}$, as well as temperature $(T)$, as proxies to represent the direct chemical effect, the indirect chemical effect, and the radiative effect result from $\mathrm{N}_{2} \mathrm{O}$ increases, respectively. Reactive hydrogen $\left(\mathrm{HO}_{\mathrm{x}}\right)$ and transport parameters are not included, since their effects are relatively small (not shown). The MLR analysis described above 

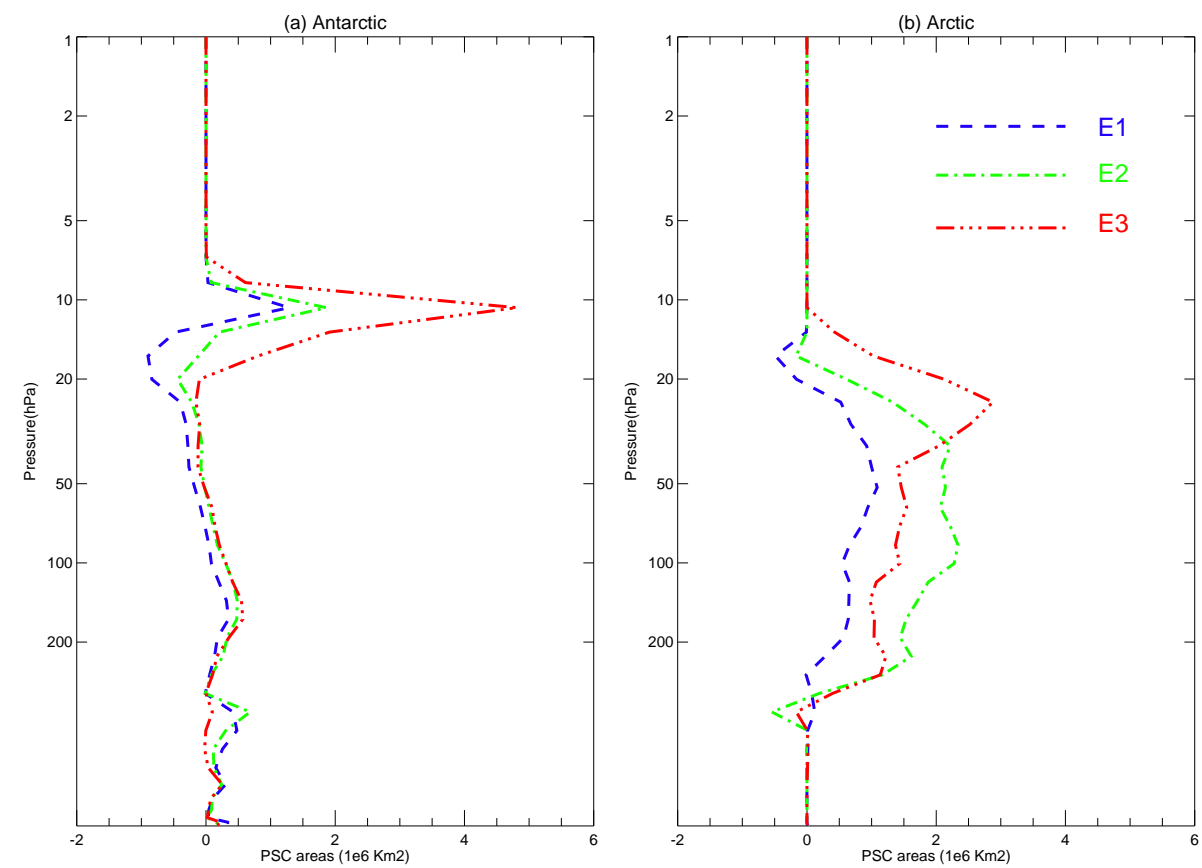

Figure 6. Profiles of differences in PSC area $\left(\times 10^{6} \mathrm{~km}^{2}\right)$ averaged over the last 10 years during winter, between WACCM experiments E1 and E0 (blue dashed line), E2 and E0 (green dashed dotted line), and E3 and E0 (red dashed dotted line) in (a) Antarctic JJA and (b) Arctic DJF.

is performed on the modelled data from the control run E0 and run E1, in which $\mathrm{N}_{2} \mathrm{O}$ is increased by $50 \%$ by 2050 . Ozone changes $\left(\Delta \mathrm{O}_{3}\right)$ caused by the selected regression factors are examined over different latitude bands (i.e. $90^{\circ} \mathrm{N}-$ $70^{\circ} \mathrm{N}, 22^{\circ} \mathrm{N}-22^{\circ} \mathrm{S}$, and $70^{\circ} \mathrm{S}-90^{\circ} \mathrm{S}$ ) on all the model levels from the surface to $1 \mathrm{hPa}$, and the results are shown in Fig. 7 . The residuals of the regressions are close to zero at all levels. The confidence level for the fits are all over $95 \%$ at all levels, and are over $99 \%$ at most of the levels from 200 to $1 \mathrm{hPa}$.

The contributions of different factors to ozone changes are strongly latitude and altitude dependent. In the Arctic, $\mathrm{NO}_{\mathrm{x}}$ and temperature changes cause ozone decreases in the lower and middle stratosphere. $\mathrm{NO}_{\mathrm{x}}$ changes, which represent the direct chemical effect of $\mathrm{N}_{2} \mathrm{O}$ increases, contribute over $80 \%$ to the $0.5 \mathrm{ppmv}$ ozone decrease from 70 to $10 \mathrm{hPa}$ (Fig. 7a). Figure $7 \mathrm{a}$ also shows that in the upper stratosphere, $\mathrm{ClO}_{\mathrm{x}}$ changes result in more ozone. In the tropics (Fig. 7b), both $T$ and $\mathrm{ClO}_{\mathrm{x}}$ changes tend to result in more ozone in the midupper stratosphere. $\mathrm{NO}_{\mathrm{x}}$ changes lead to large ozone depletion (about $150 \%$ of total ozone changes) which is partly offset (about $50 \%$ ) by the $T$ and $\mathrm{ClO}_{\mathrm{x}}$ contributions. $\mathrm{NO}_{\mathrm{x}}$ changes in the lower stratosphere cause more ozone (on the order of $0.2 \mathrm{ppmv}$ ), while $\mathrm{ClO}_{\mathrm{x}}$ and $T$ have no significant effects on ozone there. The contribution of $\mathrm{NO}_{\mathrm{x}}$ to ozone, which peaks at $10-3 \mathrm{hPa}$, is consistent with earlier studies (Oman et al., 2010b; Eyring et al., 2010b). In the Antarctic (Fig. 7c) the ozone changes caused by $\mathrm{NO}_{\mathrm{x}}$ changes are still negative but relatively small compared to those in the tropical and Arctic stratosphere. In contrast to those in the
Arctic stratosphere, ozone changes associated with $\mathrm{ClO}_{\mathrm{x}}$ are negative in the Antarctic stratosphere. Also note that $T$ has a more significant contribution to ozone changes than $\mathrm{NO}_{\mathrm{x}}$ in the Antarctic stratosphere. Similar features can be obtained when MLR analysis is performed on the model data from the control run (E0), and the run E2, in which $\mathrm{N}_{2} \mathrm{O}$ is increased by $100 \%$ by 2050 (not shown).

The above MLR analysis suggests that the direct chemical effect of $\mathrm{N}_{2} \mathrm{O}$ on ozone changes (represented by $\mathrm{NO}_{\mathrm{x}}$ ) contributes to the largest ozone changes through the whole stratosphere, while the indirect chemical effect of $\mathrm{N}_{2} \mathrm{O}$ (represented by $\mathrm{ClO}_{\mathrm{x}}$ ), which is associated with enhanced chlorine-catalysed ozone destruction, is only important for ozone depletion in the upper stratosphere in the Antarctic. The effect of change in $T$ on ozone depletion is more pronounced in the tropical upper stratosphere, but relatively less significant in the polar stratosphere. It should be pointed out that some non-linear or interdependent effects of $\mathrm{N}_{2} \mathrm{O}$ increase on ozone, such as ozone depletion associated with PSCs, may not be well separated in the MLR analysis. There may exist uncertainties in the MLR analysis because of the interdependence of the selected proxies. However, as shown in Fig. 7, the uncertainties are relatively small compared with the signal itself.

We now discuss the results of the WACCM sensitivity runs in which $\mathrm{N}_{2} \mathrm{O}$ increases are applied separately to the model's radiation and chemistry schemes. The changes in ozone and $T$, caused by chemical and radiative effects of $\mathrm{N}_{2} \mathrm{O}$ increases, are shown in Fig. 8. Ozone decreases up 

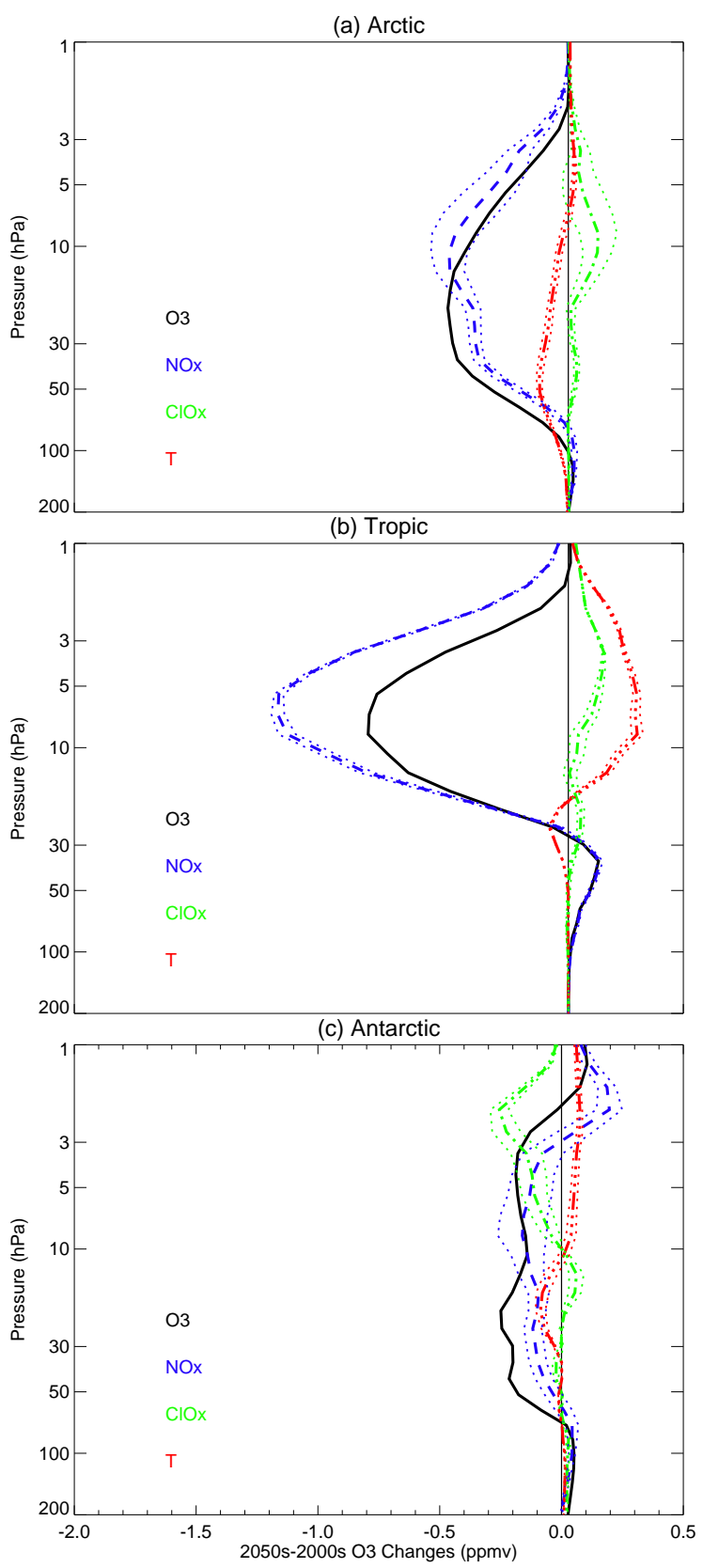

Figure 7. Results of multiple regressions for spatially averaged ozone change $\left(\Delta \mathrm{O}_{3}=\mathrm{O}_{3}(\mathrm{E} 1)-\mathrm{O}_{3}\right.$ (E0)) with spatially averaged $\mathrm{NO}_{\mathrm{x}}, \mathrm{ClO}_{\mathrm{x}}$ and $T$ change. The averaging domains are $90^{\circ} \mathrm{N}-$ $70^{\circ} \mathrm{N}, 22^{\circ} \mathrm{N}-22^{\circ} \mathrm{S}$, and $70^{\circ} \mathrm{S}-90^{\circ} \mathrm{S}$. The black thick line shows the changes of $\Delta \mathrm{O}_{3}$ from 2001 to $2050\left(d \Delta \mathrm{O}_{3}\right)$, calculated by a simple linear regression of $\Delta \mathrm{O}_{3}$ with year $\left(\Delta \mathrm{O}_{3}=a_{0}+a_{1} \times\right.$ year, $\left.d \Delta \mathrm{O}_{3}=\mathrm{a} 1 \times 50\right)$. The blue dashed line, green dashed-dotted line and red dashed double point line show the $\mathrm{NO}_{\mathrm{x}}, \mathrm{ClO}_{\mathrm{x}}$ and $T$ contributions to $\Delta \mathrm{O}_{3}$ (i.e. $d \Delta \mathrm{O}_{3, \mathrm{NO}_{x}}=\Delta \mathrm{NO}_{\mathrm{x}} \times \mathrm{Coefs}_{\mathrm{NO}_{\mathrm{x}}}$ ), respectively. The dotted lines indicate the uncertainties for the contributions, which are based on the uncertainties of the regression coefficients. to $10 \%$ (1 ppmv) relative to that of run S0 (Fig. 8a) when the $50 \% \mathrm{~N}_{2} \mathrm{O}$ increase is added to the model's chemistry scheme, while the same increase of $\mathrm{N}_{2} \mathrm{O}$ in the model's radiation scheme causes no more than $1 \%(0.1 \mathrm{ppmv})$ ozone decrease (Fig. 8b) relative to that of run SO. When $\mathrm{N}_{2} \mathrm{O}$ is increased in both the chemistry and the radiation schemes, the ozone changes show no significant differences from those caused by the chemical effect of a $50 \% \mathrm{~N}_{2} \mathrm{O}$ increase alone (not shown). It is clear that the chemical effect contributes the most to the ozone changes caused by $\mathrm{N}_{2} \mathrm{O}$ increase, which is consistent with the result of the MLR analysis. The ozone depletion causes significant subsequent stratospheric cooling, with a maximum $T$ change of $-1.5 \mathrm{~K}$ in the middle stratosphere (around $10 \mathrm{hPa}$ ) in the tropics (Fig. 8c). The direct radiative effect of $\mathrm{N}_{2} \mathrm{O}$ is much smaller (below $0.5 \mathrm{~K}$ ) than the indirect radiative effects (Fig. 8c and d) without a clear pattern in the spatial distribution.

Another factor which should also be considered is the dynamical effect of increasing $\mathrm{N}_{2} \mathrm{O}$. As listed in Table 3 , the increase in $\mathrm{N}_{2} \mathrm{O}$ is likely to strengthen the $\mathrm{BD}$ circulation, due to its direct (radiative) and indirect (ozone feedbacks) cooling effect in the stratosphere. Meanwhile, this strengthened circulation influences the distribution and also contributes to the variability of ozone. Figure 9 shows the vertical ozone flux in the control experiment E0 (Fig. 9a), as well as the corresponding changes in E1 relative to that in the run E0 (Fig. 9b) averaged over the last 10 years of model simulations.

For a given grid cell $A\left[\operatorname{lat}_{i}, \mathrm{lev}_{k}\right]$, located at latitude lat ${ }_{i}$ and pressure level $\operatorname{lev}_{k}$, the vertical ozone flux is defined as the incoming ozone at the lower level $\operatorname{lev}_{k-1}$ $\left(\mathrm{O}_{3}\left[\operatorname{lat}_{i}, \operatorname{lev}_{k-1}\right] \times w^{*}\left[\operatorname{lat}_{i}, \operatorname{lev}_{k-1}\right]\right)$ minus the ozone coming out at the higher level level $_{k+1}\left(\mathrm{O}_{3}\left[\operatorname{lat}_{i}, \operatorname{lev}_{k+1}\right] \times\right.$ $\left.w^{*}\left[\operatorname{lat}_{i}, \operatorname{lev}_{k+1}\right]\right)$. Consistent with the overall picture of the BD circulation, the ozone in the tropical lower stratosphere is transported to the upper stratosphere and ozone in the midlatitude upper stratosphere is transported downward to the lower stratosphere (Fig. 9a). It is evident from Fig. 9b that the strengthened BD circulation caused by the increased $\mathrm{N}_{2} \mathrm{O}$ leads to a net decrease of ozone in the tropical lower stratosphere and a net ozone increase at around $100 \mathrm{hPa}$ at southern mid-to-high latitudes. The large ozone increases around $100 \mathrm{hPa}$ at southern mid-latitudes, exhibited in Fig. 2a-c, may be mainly caused by this transport effect. The MLR analysis, with $w^{*}$ as an additional factor in the regression, suggests that the dynamical effect of an $\mathrm{N}_{2} \mathrm{O}$ increase on ozone changes is much less significant than its chemical and radiative effects in most areas (not shown). The result here implies that the dynamical effect of increasing $\mathrm{N}_{2} \mathrm{O}$ on ozone is small on average, but may have a significant contribution to local ozone changes in the mid-latitude stratosphere. However, it should be pointed out that there are still relatively large uncertainties in the vertical transport of tracer gases in 3-D CCMs, particularly for the latitude dependence of down- 

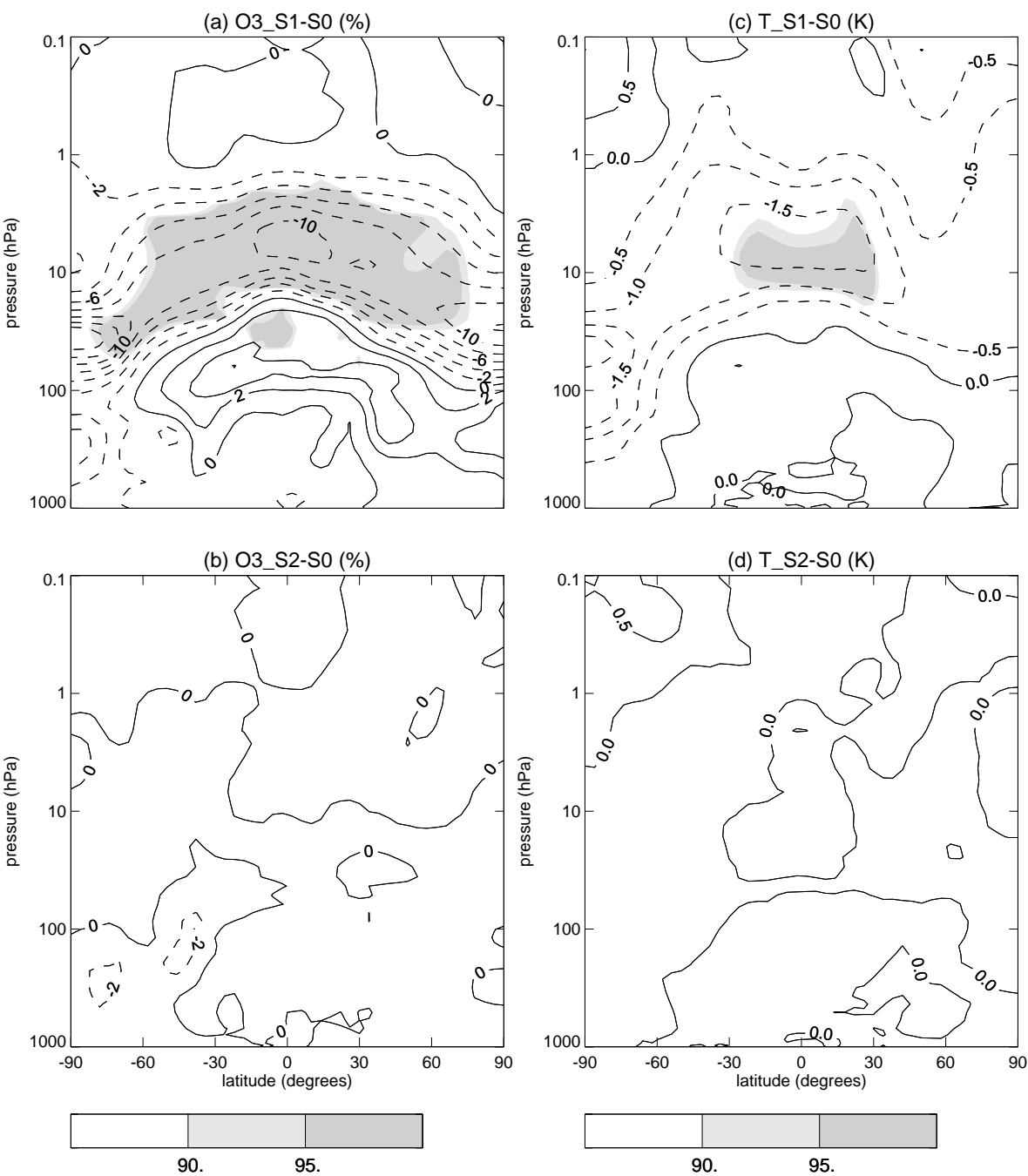

Figure 8. Latitude-pressure cross sections of zonal mean ozone differences (\%) between WACCM sensitivity experiments (a) S1 and S0, and (b) S2 and S0, and temperature differences (K) between sensitivity experiments (c) S1 and S0, and (d) S2 and S0. The contour interval for ozone is $2 \%$ and for temperature is $0.5 \mathrm{~K}$. Grey colours represent statistical significance levels for the mean state differences between different simulations by Student's $t$ test.

ward transport (Oman et al., 2010a; SPARC-CCMVal, 2010; Eyring et al., 2010a).

\section{ODP of $\mathrm{N}_{2} \mathrm{O}$ in a $\mathrm{CCM}$}

At this stage, it is worthwhile to discuss the ODP of $\mathrm{N}_{2} \mathrm{O}$. Following Ravishankara et al. (2009), the ODP of $\mathrm{N}_{2} \mathrm{O}$ relative to the reference gas $\mathrm{CFC}-11$ is computed using the following formula:

$\mathrm{ODP}_{\mathrm{N}_{2} \mathrm{O}}=\frac{m_{\mathrm{CFC} 11} \times \Delta \mu_{\mathrm{CFC} 11} \times \tau_{\mathrm{N}_{2} \mathrm{O}} \times\left[\Delta \mathrm{O}_{3}\right]_{\mathrm{N}_{2} \mathrm{O}}}{m_{\mathrm{N}_{2} \mathrm{O}} \times \Delta \mu_{\mathrm{N}_{2} \mathrm{O}} \times \tau_{\mathrm{CFC} 11} \times\left[\Delta \mathrm{O}_{3}\right]_{\mathrm{CFC} 11}}$,

where $\tau$ is the atmospheric lifetime of a given gas, $\Delta \mathrm{O}_{3}$ is the change of globally averaged column ozone, $\Delta \mu$ is the change in the mixing ratio boundary condition, and $\mathrm{m}$ is the molecular weight of the ODS. The lifetimes of $\mathrm{N}_{2} \mathrm{O}$ and CFC -11 used here are 114 and 45 years (SPARC-CCMVal, 2010), respectively.

The ODP value of $\mathrm{N}_{2} \mathrm{O}$ is estimated from three sensitivity simulations S0, S3 and S4 (Table 4) and run S0 is taken as the control run. The estimated ODP value of $\mathrm{N}_{2} \mathrm{O}$ is 0.012 under the 2050s GHG condition in the IPCC A1B scenario. This value is slightly smaller than the result obtained by Ravishankara et al. (2009) based on their 2-D simulations. The ODP values of $\mathrm{N}_{2} \mathrm{O}$ at different simulation time periods in runs E1 and E2 are also listed in Table 4. With continuously increasing $\mathrm{N}_{2} \mathrm{O}$ and changing GHG values and SSTs, the ODP values of $\mathrm{N}_{2} \mathrm{O}$ vary at different simulation time stages. The ODP value increases slightly during the first four decades of simulation time and reaches a maximum during the period 2031-2040 in both run E1 and E2. This is consistent with a previous study by Ravishankara et al. (2009) 
Table 4. $\mathrm{N}_{2} \mathrm{O}$ ODP values estimated from simulations $\mathrm{S} 3$, E1, and E2. The ODP values of $\mathrm{N}_{2} \mathrm{O}$ are calculated by equation (2). Simulations $\mathrm{S} 0$ and $\mathrm{E} 0$ are used as the control runs for estimating the ozone changes caused by $\mathrm{N}_{2} \mathrm{O}$ in simulations S3, E1, and E2. The ozone changes caused by CFC11 are estimated by the differences between runs S4 and S0. For E1 and E2 runs, the ODP values of $\mathrm{N}_{2} \mathrm{O}$ are estimated over every 10 years of simulation time.

\begin{tabular}{cccccc}
\hline Time periods & $2001-2010$ & $2011-2020$ & $2021-2030$ & $2031-2040$ & $2041-2050$ \\
\hline S3 & - & - & - & - & 0.012 \\
E1 & 0.004 & 0.006 & 0.006 & 0.008 & 0.007 \\
E2 & 0.006 & 0.007 & 0.008 & 0.009 & 0.008 \\
\hline
\end{tabular}
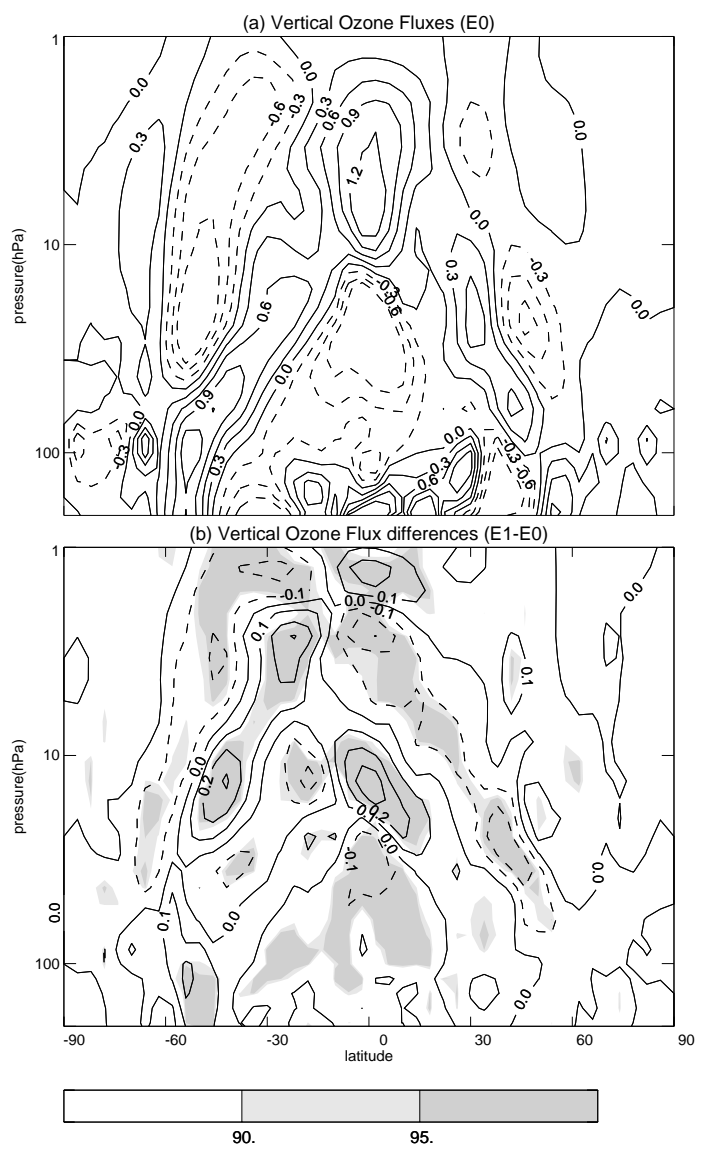

Figure 9. Vertical ozone fluxes associated with the BD circulation $\left(w^{*}\right)$ calculated from (a) reference experiment (E0) and (b) the differences between E1 and E0 (for more details of the definition of ozone flux see text) over the last 10 years. The contour intervals are $0.3 \times 10^{3} \mathrm{~kg} \mathrm{~s}^{-1}$ and $0.1 \times 10^{3} \mathrm{~kg} \mathrm{~s}^{-1}$ in (a) and (b), respectively. Grey colours (b) represent the statistical significance levels for the mean state differences between different experiments by Student's $t$ test.

which showed that the ODP of $\mathrm{N}_{2} \mathrm{O}$ will increase in the future with less stratospheric chlorine loading. It is worth pointing out that $\mathrm{N}_{2} \mathrm{O}$ ODP decreases after the simulated year 2040 , suggesting that $\mathrm{N}_{2} \mathrm{O}$ ODP does not vary linearly with $\mathrm{N}_{2} \mathrm{O}$ increases. Please also note that the ODP of $\mathrm{N}_{2} \mathrm{O}$ in the first decade of the run E1 is very small, which is because of the unstable model at the beginning of the simulation, even after 3 years of spin-up.

Though not listed in Table 4, the ODP values of $\mathrm{N}_{2} \mathrm{O}$ in E3 are very small (bellow 0.001) or even become negative, confirming that $\mathrm{CO}_{2}$ increases can strongly offset the ozone depletion effect of $\mathrm{N}_{2} \mathrm{O}$. Note that the ODP for a gas depends on the base state of the atmosphere and makes the assumption that the other source gases do not change during the time integration. It is unrealistic to keep the temperature and other sources of gases unchanged in the real atmosphere, since there exist complex interactions between various reaction cycles. Meanwhile, some reaction rates and reaction times are affected by temperatures and dynamical transport. Therefore, the ODP values estimated from our model simulations may have uncertainties. However, the results above still provide some useful information on the $\mathrm{N}_{2} \mathrm{O}$ ODP in a changing climate.

\section{Discussion and conclusions}

The distribution of ozone changes resulting from $\mathrm{N}_{2} \mathrm{O}$ increases in a 3-D CCM was discussed and the chemical-dynamical-radiative feedbacks associated with $\mathrm{N}_{2}$ Oincreases were also analysed in this study. Subsequent climate changes induced by these $\mathrm{N}_{2} \mathrm{O}$ increases, such as changes in the stratospheric temperatures, the $\mathrm{BD}$ circulation and area of PSCs, were also examined. A series of sensitivity simulations and MLR analysis were performed to detect the dominant factors controlling the ozone changes caused by $\mathrm{N}_{2} \mathrm{O}$ increases, and to understand the $\mathrm{N}_{2} \mathrm{O}$ ODP in a changing climate.

The CCM results suggest that $\mathrm{N}_{2} \mathrm{O}$ increases by $50 \% / 100 \%$ between 2001 and 2050 result in more ozone destruction with a decrease of ozone mixing ratios up to $6 \% / 10 \%$ in the middle stratosphere at around $10 \mathrm{hPa}$. However, the TCO still shows an increase in future decades. The increase of $\mathrm{N}_{2} \mathrm{O}$ also results in a slight cooling in the stratosphere due to its indirect radiative effects. In a future cooler stratosphere the net yield of $\mathrm{NO}_{\mathrm{y}}$ is known to decrease, but our simulations indicate that it can still be significantly increased when $\mathrm{N}_{2} \mathrm{O}$ increases. The increase of $\mathrm{N}_{2} \mathrm{O}$ has only a small influence on chemical processes associated with Antarctic ozone destruction. However, increased emis- 
sions of $\mathrm{N}_{2} \mathrm{O}$ have a significant impact on the ozone layer in the Arctic stratosphere.

The results from a series of sensitivity simulations and MLR analysis suggest that $\mathrm{N}_{2} \mathrm{O}$ increases affect ozone mainly through chemical processes. The direct chemical effect of $\mathrm{N}_{2} \mathrm{O}$ increases (via $\mathrm{NO}_{\mathrm{x}}$ chemistry) contributes the majority of ozone changes in the stratosphere, while the indirect chemical effect of $\mathrm{N}_{2} \mathrm{O}$ increases (via halogen chemistry) is simulated as the dominant factor in ozone depletion in the Antarctic upper stratosphere. The direct radiative effect of $\mathrm{N}_{2} \mathrm{O}$ increases on ozone is rather weak, but the indirect radiative effect associated with ozone changes is evident and coupled with chemical and dynamical processes. The dynamical effect of increasing $\mathrm{N}_{2} \mathrm{O}$ is also overall insignificant, but can cause large local ozone changes in the mid-latitude lower stratosphere/upper troposphere. The ozone depleting effect of $\mathrm{N}_{2} \mathrm{O}$ increases can be significantly reduced in the middle and upper stratosphere when $\mathrm{CO}_{2}$ is also increased, implying that the depletion of ozone caused by $\mathrm{N}_{2} \mathrm{O}$ increases depends strongly on stratospheric temperature changes. Further analysis of the $\mathrm{N}_{2} \mathrm{O}$ ODP reveals that $\mathrm{N}_{2} \mathrm{O}$ ODP does not vary linearly with $\mathrm{N}_{2} \mathrm{O}$ increases, and is influenced by various factors, e.g. $\mathrm{CO}_{2}$ increases can strongly offset the ozone depletion effect of $\mathrm{N}_{2} \mathrm{O}$.

Acknowledgements. This work was supported by the National Science Foundation of China $(41175042,41225018)$ and National Basic Research Program of China (2010CB428604). We also thank the Fundamental Research Funds for the Central Universities of China and the computing resources from Supercomputing Center of Cold and Arid Region Environment and Engineering Research Institute of Chinese Academy of Sciences. We thank Martyn Chipperfield from the University of Leeds for comments on the manuscript, Lisa Neef from GEOMAR for grammar checking and Shaojie Ma and Guohui Zhao for help in data processing. We thank the editor and reviewers for their helpful comments and suggestions.

Edited by: G. Stiller

\section{References}

Austin, J. and Wilson, R. J.: Ensemble simulations of the decline and recovery of stratospheric ozone, J. Geophys. Res., 111, D16314, doi:10.1029/2005JD006907, 2006.

Austin, J., Scinocca, J., Plummer, D., Oman, L., Waugh, D., Akiyoshi, H., Bekki, S., Braesicke, P., Butchart, N., Chipperfield, M., Cugnet, D., Dameris, M., Dhomse, S., Eyring, V., Frith, S., Garcia, R. R., Garny, H., Gettelman, A., Hardiman, S. C., Kinnison, D., Lamarque, J. F., Mancini, E., Marchand, M., Michou, M., Morgenstern, O., Nakamura, T., Pawson, S., Pitari, G., Pyle, J., Rozanov, E., Shepherd, T. G., Shibata, K., Teyssèdre, H., Wilson, R. J., and Yamashita, Y.: Decline and recovery of total column ozone using a multimodel time series analysis, J. Geophys. Res., 115, D00M10, doi:10.1029/2010JD013857, 2010a.
Austin, J., Struthers, H., Scinocca, J., Plummer, D. A., Akiyoshi, H., Baumgaertner, A. J. G., Bekki, S., Bodeker, G. E., Braesicke, P., Brühl, C., Butchart, N., Chipperfield, M. P., Cugnet, D., Dameris, M., Dhomse, S., Frith, S., Garny, H., Gettelman, A., Hardiman, S. C., Jöckel, P., Kinnison, D., Kubin, A., Lamarque, J. F., Langematz, U., Mancini, E., Marchand, M., Michou, M., Morgenstern, O., Nakamura, T., Nielsen, J. E., Pitari, G., Pyle, J., Rozanov, E., Shepherd, T. G., Shibata, K., Smale, D., Teyssèdre, H., and Yamashita, Y.: Chemistry-climate model simulations of spring Antarctic ozone, J. Geophys. Res., 115, D00M11, doi:10.1029/2009JD013577, 2010b.

Brasseur, G. and Hitchman, M. H.: Stratospheric response to trace gas perturbations: changes in ozone and temperature distributions, Science, 240, 634-637, doi:10.1126/science.240.4852.634, 1988.

Chipperfield, M.: Atmospheric science: nitrous oxide delays ozone recovery, Nat. Geosci., 2, 742-743, doi:10.1038/ngeo678, 2009.

Chipperfield, M., Feng, W., and Rex, M.: Arctic ozone loss and climate sensitivity: updated three-dimensional model study, Geophys. Res. Lett., 32, L11813, doi:10.1029/2005GL022674, 2005.

Chipperfield, M. P.: Comment on: "Stratospheric Ozone Depletion at northern mid-latitudes in the 21 st century: the importance of future concentrations of greenhouse gases nitrous oxide and methane", Geophys. Res. Lett., 30, 1389, doi:10.1029/2002GL016353, 2003.

Crutzen, P. J.: Upper limits on atmospheric ozone reductions following increased application of fixed nitrogen to the soil, Geophys. Res. Lett., 3, 169-172, doi:10.1029/GL003i003p00169, 1976.

Crutzen, P. J. and Ehhalt, D. H.: Effects of nitrogen fertilizers and combustion on the stratospheric ozone layer, Ambio, 6, 112-117, 1977.

Dameris, M.: Depletion of the ozone layer in the $21 \mathrm{st}$ century., Angew. Chem. Int. Edit., 49, 489-491, doi:10.1002/anie.200906334, 2010.

Daniel, J. S., Fleming, E. L., Portmann, R. W., Velders, G. J. M., Jackman, C. H., and Ravishankara, A. R.: Options to accelerate ozone recovery: ozone and climate benefits, Atmos. Chem. Phys., 10, 7697-7707, doi:10.5194/acp-10-7697-2010, 2010.

Dentener, F., Stevenson, D., Cofala, J., Mechler, R., Amann, M., Bergamaschi, P., Raes, F., and Derwent, R.: The impact of air pollutant and methane emission controls on tropospheric ozone and radiative forcing: CTM calculations for the period 19902030, Atmos. Chem. Phys., 5, 1731-1755, doi:10.5194/acp-51731-2005, 2005.

Eyring, V., Waugh, D., Bodeker, G., Cordero, E., Akiyoshi, H., Austin, J., Beagley, S., Boville, B., Braesicke, P., Brühl, C., C., Butchart, N., Chipperfield, M. P., Dameris, M., Deckert, R., Deushi, M., Frith, S. M., Garcia, R. R., Gettelman, A., Giorgetta, M. A., Kinnison, D. E., Mancini, E., Manzini, E., Marsh, D. R., Matthes, S., Nagashima, T., Newman, P. A., Nielsen, J. E., Pawson, S., Pitari, G., Plummer, D. A., Rozanov, E., Schraner, M., Scinocca, J. F., Semeniuk, K., Shepherd, T. G., Shibata, K., Steil, B., Stolarski, R. S., Tian,W., and Yoshiki, M: Multimodel projections of stratospheric ozone in the 21st century, J. Geophys. Res., 112, D16303, doi:10.1029/2006JD008332, 2007.

Eyring, V., Chipperfield, M., Giorgetta, M., Kinnison, D. E., Manzini, E., Matthes, K., Newman, P., Pawson, S., Shepherd, T., andWaugh, D.: Overview of the new CCMVal reference and 
sensitivity simulations in support of upcoming ozone and climate assessments and planned SPARC CCMVal, SPARC Newsletter, 30, 20-26, 2008.

Eyring, V., Cionni, I., Bodeker, G. E., Charlton-Perez, A. J., Kinnison, D. E., Scinocca, J. F., Waugh, D. W., Akiyoshi, H., Bekki, S., Chipperfield, M. P., Dameris, M., Dhomse, S., Frith, S. M., Garny, H., Gettelman, A., Kubin, A., Langematz, U., Mancini, E., Marchand, M., Nakamura, T., Oman, L. D., Pawson, S., Pitari, G., Plummer, D. A., Rozanov, E., Shepherd, T. G., Shibata, K., Tian, W., Braesicke, P., Hardiman, S. C., Lamarque, J. F., Morgenstern, O., Pyle, J. A., Smale, D., and Yamashita, Y.: Multi-model assessment of stratospheric ozone return dates and ozone recovery in CCMVal-2 models, Atmos. Chem. Phys., 10, 9451-9472, doi:10.5194/acp-10-9451-2010, 2010a.

Eyring, V., Cionni, I., Lamarque, J. F., Akiyoshi, H., Bodeker, G. E., Charlton-Perez, A. J., Frith, S. M., Gettelman, A., Kinnison, D. E., Nakamura, T., Oman, L. D., Pawson, S., and Yamashita, Y.: Sensitivity of 21 st century stratospheric ozone to greenhouse gas scenarios, Geophys. Res. Lett., 37, L16807, doi:10.1029/2010GL044443, 2010b.

Fleming, E. L., Jackman, C. H., Stolarski, R. S., and Douglass, A. R.: A model study of the impact of source gas changes on the stratosphere for 1850-2100, Atmos. Chem. Phys., 11, 8515-8541, doi:10.5194/acp-11-8515-2011, 2011.

Garcia, R. R., Marsh, D. R., Kinnison, D. E., Boville, B. A., and Sassi, F.: Simulation of secular trends in the middle atmosphere, 1950-2003, J. Geophys. Res., 112, D09301, doi:10.1029/2006JD007485, 2007.

Haigh, J. and Pyle, J.: Ozone perturbation experiments in a twodimensional circulation model, Q. J. Roy. Meteor. Soc., 108, 551-574, doi:10.1002/qj.49710845705, 1982.

Hauglustaine, D., Brasseur, G., Walters, S., Rasch, P., Müller, J.F., Emmons, L., and Carroll, M.: MOZART, a global chemical transport model for ozone and related chemical tracers: 2. Model results and evaluation, J. Geophys. Res., 103, 2829128335, doi:10.1029/98JD02398, 1998.

Horowitz, L. W., Walters, S., Mauzerall, D. L., Emmons, L. K., Rasch, P. J., Granier, C., Tie, X., Lamarque, J.-F., Schultz, M. G., Tyndall, G. S., Orlando, J. J., and Brasseur, G. P.: A global simulation of tropospheric ozone and related tracers: description and evaluation of MOZART, version 2, J. Geophys. Res., 108, 4784, doi:10.1029/2002JD002853, 2003.

Kinnison, D., Johnston, H., and Wuebbles, D.: Ozone calculations with large nitrous oxide and chlorine changes, J. Geophys. Res., 93, 14165-14175, doi:10.1029/JD093iD11p14165, 1988.

Lin, S.-J.: A “vertically Lagrangian" finite-volume dynamical core for global models, Mon. Weather Rev., 132, 2293-2307, 2004.

Morgenstern, O., Giorgetta, M. A., Shibata, K., Eyring, V., Waugh, D. W., Shepherd, T. G., Akiyoshi, H., Austin, J., Baumgaertner, A. J. G., Bekki, S., Braesicke, P., Brühl, C., Chipperfield, M. P., Cugnet, D., Dameris, M., Dhomse, S., Frith, S. M., Garny, H., Gettelman, A., Hardiman, S. C., Hegglin, M. I., Jöckel, P., Kinnison, D. E., Lamarque, J.F., Mancini, E., Manzini, E., Marchand, M., Michou, M., Nakamura, T., Nielsen, J. E., Olivié, D., Pitari, G., Plummer, D. A., Rozanov, E., Scinocca, J. F., Smale, D., Teyssèdre, H., Toohey, M., Tian, W., and Yamashita, Y.: Review of the formulation of present-generation stratospheric chemistry- climate models and associated external forcings, J. Geophys. Res., 115, D00M02, doi:10.1029/2009JD013728, 2010.

Newman, P. A., Nash, E. R., Kawa, S. R., Montzka, S. A., and Schauffler, S. M.: When will the Antarctic ozone hole recover?, Geophys. Res. Lett., 33, L12814, doi:10.1029/2005GL025232, 2006.

Oberländer, S., Langematz, U., and Meul, S.: Unraveling impact factors for future changes in the Brewer-Dobson circulation, Journal of Geophysical Research: Atmospheres, 118, 10-296, doi:10.1002/jgrd.50775, 2013.

Oman, L. D., Plummer, D. A., Waugh, D. W., Austin, J., Scinocca, J. F., Douglass, A. R., Salawitch, R. J., Canty, T., Akiyoshi, H., Bekki, S., Braesicke, P., Butchart, N., Chipperfield, M. P., Cugnet, D., Dhomse, S., Eyring, V., Frith, S., Hardiman, S. C., Kinnison, D. E., Lamarque, J.-F., Mancini, E., Marchand, M., Michou, M., Morgenstern, O., Nakamura, T., Nielsen, J. E., Olivié, D., Pitari, G., Pyle, J., Rozanov, E., Shepherd, T. G., Shibata, K., Stolarski, R. S., Teyssèdre, H., Tian, W., Yamashita, Y., and Ziemke, J. R.: Multimodel assessment of the factors driving stratospheric ozone evolution over the 21st century, J. Geophys. Res., 115, D24306, doi:10.1029/2010JD014362, 2010a.

Oman, L. D., Waugh, D. W., Kawa, S. R., Stolarski, R. S., Douglass, A. R., and Newman, P. A.: Mechanisms and feedback causing changes in upper stratospheric ozone in the 21st century, J. Geophys. Res., 115, D05303, doi:10.1029/2009JD012397, $2010 b$.

Portmann, R. W. and Solomon, S.: Indirect radiative forcing of the ozone layer during the 21 st century, Geophys. Res. Lett., 34, L02813, doi:10.1029/2006GL028252, 2007.

Portmann, R., Daniel, J., and Ravishankara, A.: Stratospheric ozone depletion due to nitrous oxide: influences of other gases, Philosophical Transactions of the Royal Society B: Biological Sciences, 367, 1256-1264, doi:10.1098/rstb.2011.0377, 2012.

Randeniya, L., Vohralik, P., and Plumb, I.: Stratospheric ozone depletion at northern mid latitudes in the 21st century: the importance of future concentrations of greenhouse gases nitrous oxide and methane, Geophys. Res. Lett., 29, 1051, doi:10.1029/2001GL014295, 2002.

Ravishankara, A. R., Daniel, J. S., and Portmann, R. W.: Nitrous oxide $\left(\mathrm{N}_{2} \mathrm{O}\right)$ : the dominant ozone-depleting substance emitted in the 21st century., Science, 326, 123-125, doi:10.1126/science.1176985, 2009.

Rayner, N., Parker, D., Horton, E., Folland, C., Alexander, L., Rowell, D., Kent, E., and Kaplan, A.: Global analyses of sea surface temperature, sea ice, and night marine air temperature since the late nineteenth century, J. Geophys. Res., 108, 4407, doi:10.1029/2002JD002670, 2003.

Revell, L., Bodeker, G., Huck, P., Williamson, B., and Rozanov, E.: The sensitivity of stratospheric ozone changes through the $21 \mathrm{st}$ century to $\mathrm{N} 2 \mathrm{O}$ and $\mathrm{CH} 4$, Atmospheric Chemistry and Physics, 12, 11 309-11317, doi:10.5194/acp-12-11309-2012, 2012a.

Revell, L., Bodeker, G., Smale, D., Lehmann, R., Huck, P., Williamson, B., Rozanov, E., and Struthers, H.: The effectiveness of N2O in depleting stratospheric ozone, Geophysical Research Letters, 39, 1-6, doi:10.1029/2012GL052143, 2012 b.

Rex, M., Salawitch, R., von der Gathen, P., Harris, N., Chipperfield, M., and Naujokat, B.: Arctic ozone loss 
and climate change, Geophys. Res. Lett., 31, 4116, doi:10.1029/2003GL018844, 2004.

Röckmann, T., Grooß, J.-U., and Müller, R.: The impact of anthropogenic chlorine emissions, stratospheric ozone change and chemical feedbacks on stratospheric water, Atmos. Chem. Phys., 4, 693-699, doi:10.5194/acp-4-693-2004, 2004.

Rosenfield, J. E. and Douglass, A. R.: Doubled $\mathrm{CO}_{2}$ effects on $\mathrm{NO}_{\mathrm{y}}$ in a coupled 2-D model, Geophys. Res. Lett., 25, 4381-4384, doi:10.1029/1998GL900147, 1998.

Rosenfield, J. E., Douglass, A. R., and Considine, D. B.: The impact of increasing carbon dioxide on ozone recovery, J. Geophys. Res., 107, ACH7-1-ACH7-9, doi:10.1029/2001JD000824, 2002.

Sander, S. P., Golden, D., Kurylo, M., Moortgat, G., Wine, P., Ravishankara, A., Kolb, C., Molina, M., Finlayson-Pitts, B., Huie, R., et al.: Chemical kinetics and photochemical data for use in atmospheric studies evaluation number 15, JPL Publ., 06-2, 523 pp, 2006.

Shepherd, T. G.: Dynamics, stratospheric ozone, and climate change, Atmos. Ocean, 46, 117-138, doi:10.3137/ao.460106, 2008.

SPARC CCMVal, SPARC Report on the Evaluation of ChemistryClimate Models, edited by: Eyring, V., Shepherd, T. G., and Waugh, D. W., SPARC Report No. 5, WCRP-132, WMO/TDNo. 1526, available at: http://www.sparc-climate.org/publications/ sparc-reports/sparc-report-no5/ SPARC, 2010.
Stenke, A. and Grewe, V.: Simulation of stratospheric water vapor trends: impact on stratospheric ozone chemistry, Atmos. Chem. Phys., 5, 1257-1272, doi:10.5194/acp-5-1257-2005, 2005.

Stolarski, R. S., Douglass, A. R., Newman, P. A., Pawson, S., and Schoeberl, M. R.: Relative contribution of greenhouse gases and ozone-depleting substances to temperature trends in the stratosphere: a chemistry-climate model study, J. Climate., 23, 28-42, doi:10.1175/2009JCLI2955.1, 2010.

Tian, W. and Chipperfield, M. P.: A new coupled chemistry-climate model for the stratosphere: the importance of coupling for future $\mathrm{O}_{3}$-climate predictions, Q. J. Roy. Meteor. Soc., 131, 281-303, doi:10.1256/qj.04.05, 2005.

Tian, W., Chipperfield, M. P., and Lü, D.: Impact of increasing stratospheric water vapor on ozone depletion and temperature change, Adv. Atmos. Sci., 26, 423-437, doi:10.1007/s00376009-0423-3, 2009.

WMO: Scientific assessment of ozone depletion: 2006, World Meteorological Organisation, Global Ozone Research and Monitoring Project-Report, Geneva, Switzerland, 50, 572, 2007.

Wuebbles, D. J.: Nitrous oxide: no laughing matter, Science, 326 , 56-57, doi:10.1126/science.1179571, 2009.

Wuebbles, D. J. and Hayhoe, K.: Atmospheric methane and global change, Earth-Sci. Rev., 57, 177-210, doi:10.1016/S00128252(01)00062-9, 2002.

Xie, F., Tian, W., and Chipperfield, M. P.: Radiative effect of ozone change on stratosphere-troposphere exchange, J. Geophys. Res., 113, D00B09, doi:10.1029/2008JD009829, 2008. 